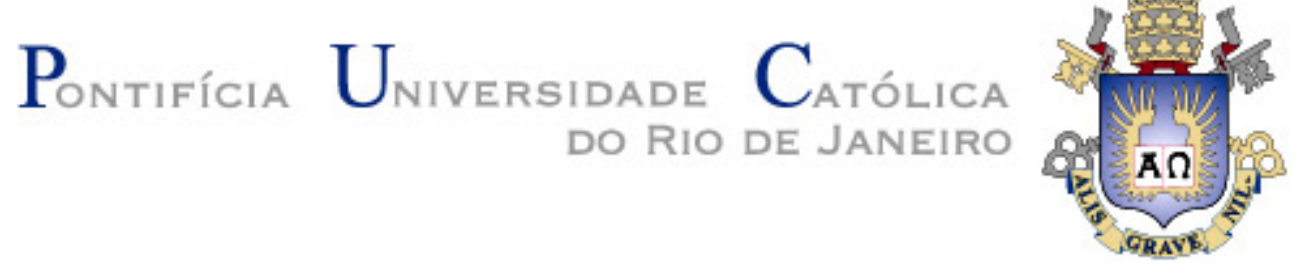

Alexandre Yutaca Ikenami

Estudo sobre lealdade de clientes no mercado de seguros de automóveis: uma abordagem via equações estruturais

Dissertação de Mestrado

Dissertação apresentada ao Programa de Pós-graduação em Administração de Empresas da PUC-Rio como requisito parcial para obtenção do grau de Mestre em Administração de Empresas.

Orientador: Prof. Jorge Brantes Ferreira 
Alexandre Yutaca Ikenami

\title{
Estudo sobre lealdade de clientes no mercado de seguros de automóveis: uma abordagem via equações estruturais
}

\begin{abstract}
Dissertação apresentada como requisito parcial para obtenção do grau de Mestre pelo Programa de Pós-Graduação em Administração de Empresas da PUC-Rio. Aprovada pela Comissão Examinadora abaixo assinada.
\end{abstract}

Prof. Jorge Brantes Ferreira Orientador Departamento de Administração - PUC-Rio

Prof. Marcus Wilcox Hemais Departamento de Administração - PUC-Rio

Prof. José Mauro Gonçalves Nunes

UERJ

Profa. Mônica Herz Vice-Decana de Pós-Graduação do CCS - PUC-Rio 
Todos os direitos reservados. É proibida a reprodução total ou parcial do trabalho sem autorização da universidade, do autor e do orientador.

\section{Alexandre Yutaca Ikenami}

Graduação em Administração de Empresas com ênfase em Seguros pela ESNS - Escola Superior Nacional de Seguros em 2013. Analista de Resseguro em uma empresa de seguro e resseguro. Início das atividades no mestrado profissional em Administração de Empresas com ênfase em Marketing em 2015.

Ficha Catalográfica 


\section{Agradecimentos}

Ao meu orientador Professor Jorge Brantes Ferreira pelos ensinamentos. Sem eles, não seria possível a realização deste trabalho.

Aos professores participantes da Comissão examinadora.

Aos amigos de Botafogo, em especial ao Professor Maurício pelo incentivo a ingressar no mestrado.

Aos meus pais e aos meus irmãos, por todo carinho e dedicação ao longo de todos os anos.

À minha esposa Andreza, pelo amor presente em todas as horas.

À minha filha Catarina, por tornar nossa casa um lar luminoso e alegre.

Agradeço a Álvaro del Portillo, por toda ajuda nos momentos mais difíceis.

A Deus, a quem ofereço todo esforço e sacrifício desta caminhada. 


\section{Resumo}

Ikenami, Alexandre Yutaca; Ferreira, Jorge Brantes (Orientador). Estudo sobre lealdade de clientes no mercado de seguros de automóveis: uma abordagem via equações estruturais. Rio de Janeiro, 2017. 77p. Dissertação de Mestrado - Departamento de Administração, Pontifícia Universidade Católica do Rio de Janeiro.

O mercado de seguro de automóvel no Brasil apresenta uma concorrência agressiva, indicando que as seguradoras devem investir na fidelização de clientes para buscar sua sobrevivência. Dado isso, este estudo visa testar e analisar hipóteses que abordam a formação da lealdade do cliente no seguro de automóvel com base na análise de efeitos de antecedentes relevantes, como satisfação, custo da mudança, atratividade das alternativas e confiança. A revisão da literatura apresenta e discute modelos de lealdade de acordo com os estudos de Picón et al. (2014) e Aurier e N'Goala, (2010). Por meio de uma survey, foi coletada uma amostra de 230 segurados de automóvel. A análise dos dados e o teste das hipóteses propostas foi realizada por meio de modelagem de equações estruturais. Os resultados indicam que satisfação, confiança, atratividade das alternativas e custos de troca impactam diretamente na lealdade do consumidor no mercado de seguro de automóvel.

\section{Palavras-chave}

Lealdade do consumidor; seguros de automóvel; equações estruturais. 


\section{Abstract}

Ikenami, Alexandre Yutaca; Ferreira, Jorge Brantes (Advisor). Customer loyalty in the motor insurance market: based on SEM. Rio de Janeiro, 2017. 77p. Dissertação de Mestrado - Departamento de Administração, Pontifícia Universidade Católica do Rio de Janeiro.

The car insurance market in Brazil presents aggressive competition, indicating that insurers should invest in customer loyalty to survive. Thus, this study aims to test and analyze hypotheses that address customer loyalty in the insurance market based on the analysis of relevant antecedents of loyalty, such as satisfaction, switching costs, attractiveness of the alternatives and trust. The literature review presents and discusses loyalty models according to Picón et al. (2014) and Aurier and N'Goala, (2010). Through a survey, a sample of 230 automobile insurance clients was collected. The proposed model was analyzed via structural equations modeling. The results show that satisfaction, trust, attractiveness of alternatives and switching cost directly affect loyalty in the car insurance industry.

\section{Keywords}

Customer loyalty; motor insurance; SEM. 


\section{Sumário}

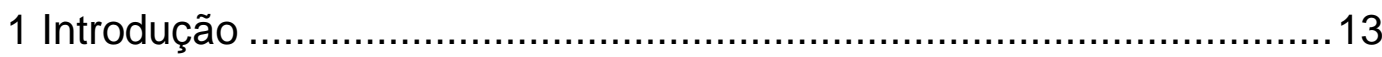

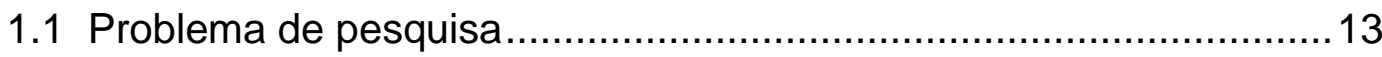

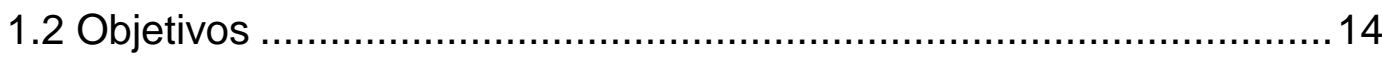

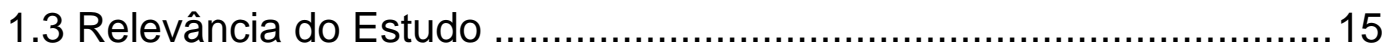

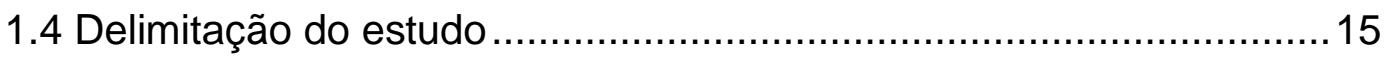

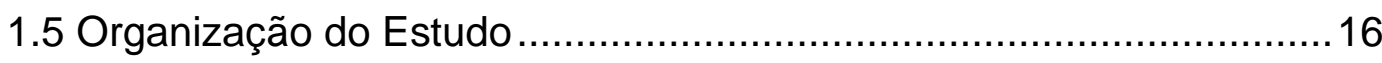

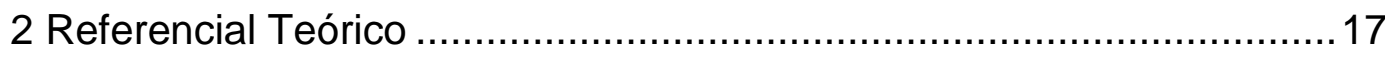

2.1 Relevância da lealdade no contexto organizacional..........................17

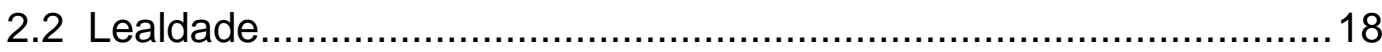

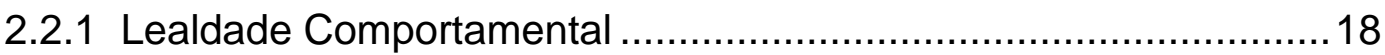

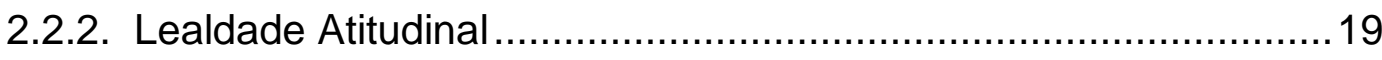

2.2.3. Modelo integrado de Dick e Basu (1994) .....................................21

2.2.4. Modelo integrado de Oliver (1997) ..........................................22

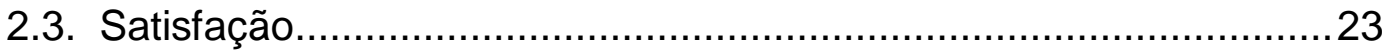

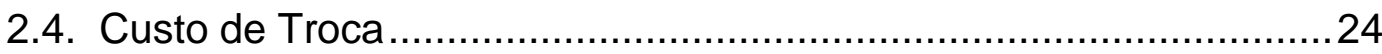

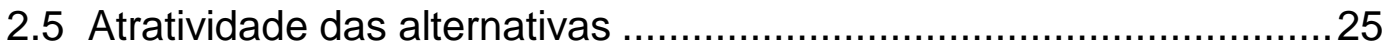

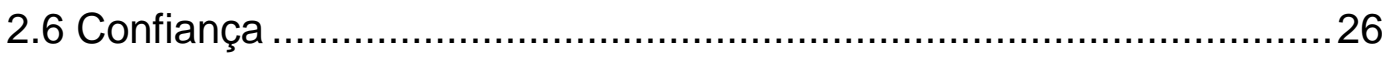

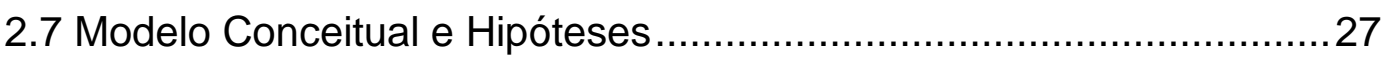

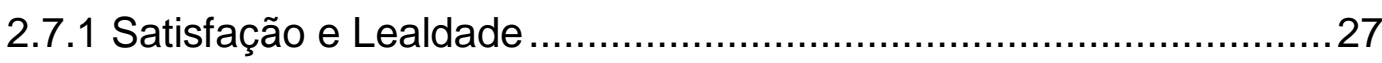

2.7.2 Satisfação, Custo de Troca e Lealdade.........................................28

2.7.3 Satisfação, Atratividade das Alternativas e Lealdade.......................29

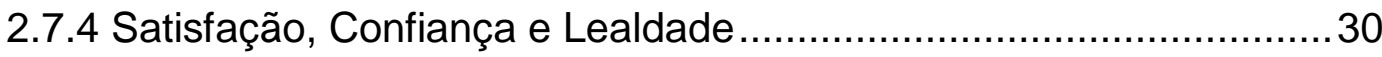

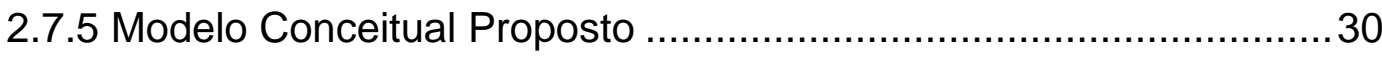

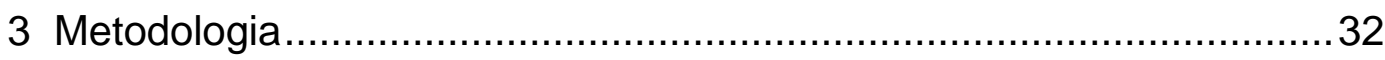

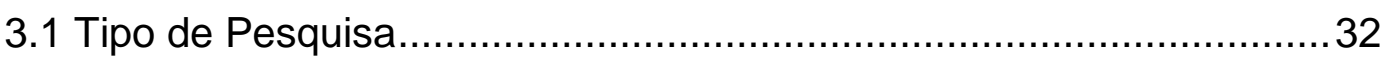

3.2 Operacionalização e Definição das Variáveis ...................................32

3.2.1 Definição Operacional das Variáveis..............................................33

3.2.2 Procedimentos de Tradução e Adaptação das Escalas Utilizadas.. 36

3.2.3 Pré-teste do Instrumento de Pesquisa ........................................... 36

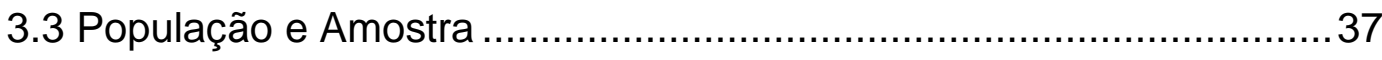




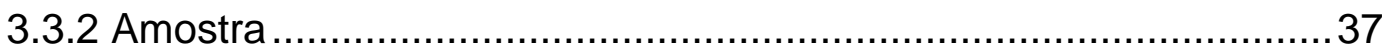

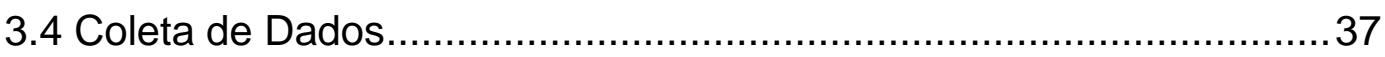

3.4.1 O Instrumento de Coleta de Dados ........................................ 37

3.4.2 A Coleta de Dados ...................................................... 38

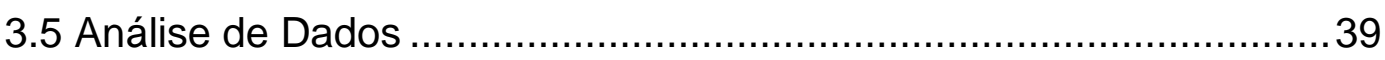

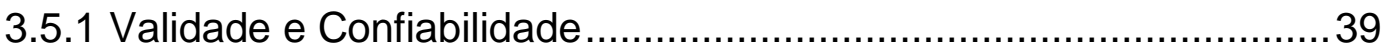

3.5.2 Análises Estatísticas ............................................................40

3.6 Limitações do Método ..........................................................40

3.6.1 Limitações relacionadas ao critério de amostragem .....................40

3.6.2 Limitações decorrentes da coleta de dados ...............................41

4. Modelagem e análise de dados.............................................. 42

4.1 Caracterização da Amostra ..................................................42

4.2 Análises e Resultados ........................................................... 45

4.2.1 Avaliação do Modelo de Mensuração ........................................ 45

4.2.2 Validade e Confiabilidade dos Construtos ..................................46

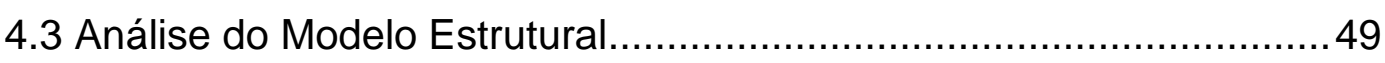

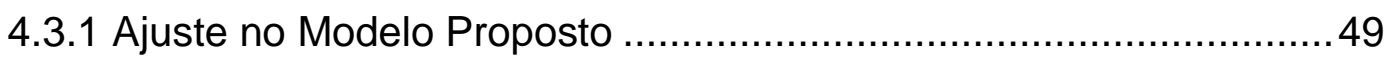

4.3.2 Teste das Hipóteses de Pesquisa ...........................................50

4.4 Discussão dos Resultados ................................................... 52

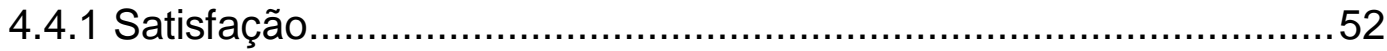

4.4.2 Custo de Troca, Atratividade das Alternativas e Lealdade ..............54

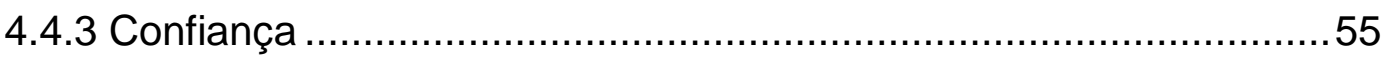

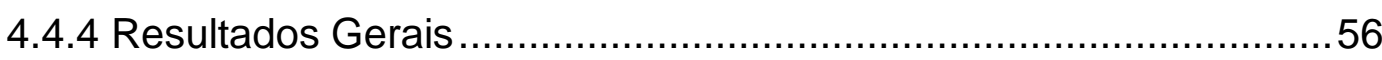

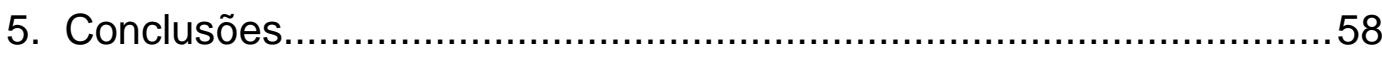

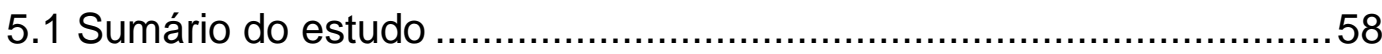

5.2 Conclusões e implicações .......................................................59

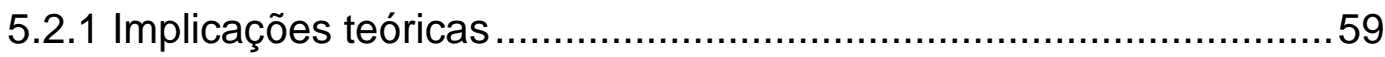

5.2 .2 Implicações práticas .......................................................... 60

5.3 Limitações do estudo ........................................................ 60

5.4 Sugestões para pesquisas futuras ......................................... 61

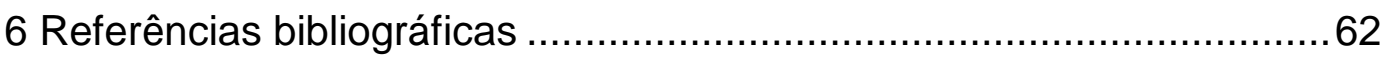


Apêndice A - Questionário utilizado na pesquisa ..............................69

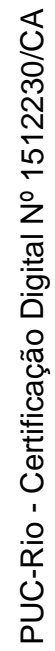




\section{Lista de figuras}

Figura 2.1: Modelo Conceitual Proposto .............................................. 19

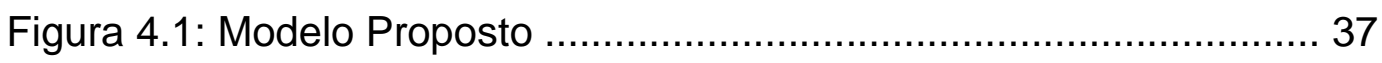

Figura 4.2: Modelo Proposto, Coeficientes Padronizados e

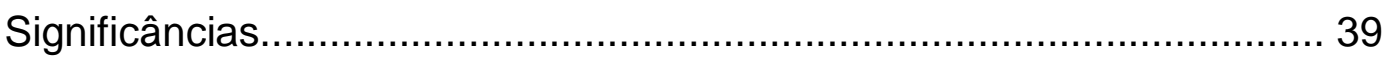

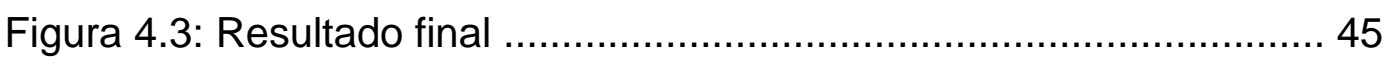




\section{Lista de tabelas}

Tabela 4.1: Confiabilidade Composta e Variância Extraída Média

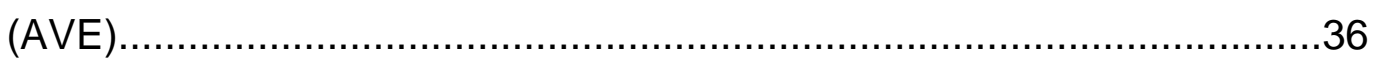

Tabela 4.2: Índices de Ajuste do Modelo ............................................. 38

Tabela 4.3: Coeficientes Padronizados Estimados, Hipóteses e

Significâncias para o Modelo proposto..................................................39 


\section{Lista de quadros}

Quadro 3.1: Definições operacionais das variáveis .............................. 21

Quadro 4.1: Características da Amostra ............................................. 31

Quadro 4.2: Matriz de Correlação entre Construtos .............................. 35

Quadro 4.3: Matriz de Validade Discriminante ………........................... 36 


\section{1 \\ Introdução}

\section{1 \\ Problema de pesquisa}

Qualquer atividade humana envolve perigos e incertezas. Buscando proteger seu patrimônio o homem transfere o risco de prejuízos financeiros para uma instituição seguradora por meio da contratação de apólices de seguros (FUNENSEG, 2010). No ano de 2016, segundo números da Superintendência de Seguros Privados (SUSEP), o mercado securitário movimentou $\mathrm{R} \$ 360$ bilhões de reais, valores que representam 3,8\% do PIB do Brasil. Portanto, a atividade seguradora possui uma participação relevante na economia nacional, tendo crescimento de $4 \%$ no último ano, mesmo com o contexto macroeconômico desfavorável.

Segundo pesquisa realizada pela KPMG em 2014, a rentabilidade apurada era consistente nas linhas de varejo e apresentava ainda um potencial de crescimento para os anos seguintes. Por isso, muitas empresas do exterior, atraídas por essa perspectiva positiva, alocaram capital estrangeiro para iniciar suas operações no país. De acordo com a mesma pesquisa, a entrada de novos players contribuiu para o aumento na concorrência, para uma maior demanda por mão-de-obra especializada e para a necessidade de redução nas margens de lucro, culminando assim na maior oferta e diversificação de produtos. Esta evolução do mercado de seguros exigiu a elaboração de um planejamento estratégico competitivo de longo prazo.

De acordo com a Confederação Nacional das Empresas de Seguros (CNSEG, 2016), dentro deste mercado, o seguro de automóvel apresentou um volume total de $\mathrm{R} \$ 3$ bilhões de prêmio emitido no ano passado, representando $50 \%$ da participação de seguros de danos em 2016. Segundo o Instituto Brasileiro de Geografia e Estatística (IBGE), atualmente, a frota de automóvel no Brasil chegou à marca de 50 milhões veículos, um número expressivo mesmo com a queda nas vendas da indústria automotiva nos últimos anos. Essa quantidade de veículos representa para as seguradoras, um negócio de 5,5 milhões de apólices por ano (CNSEG, 2016). Todavia, o desempenho da carteira ainda é bastante imprevisível, com uma sinistralidade alta de 70\% (CNSEG, 
2016), fato que, somado à queda do emprego e à diminuição da renda média do brasileiro, exige das seguradoras eficiência operacional, investimento em tecnologias e desenvolvimento de estratégias de vendas avançadas.

A própria natureza do negócio, fatores econômicos adversos e agressividade do mercado trazem desafios aos executivos que estão à frente das seguradoras e continuam enfrentando obstáculos significativos ao tentar alavancar seu lucro e aumentar sua participação de mercado. Uma das estratégias possíveis para atingir esses objetivos é focar na retenção de clientes.

Com este cenário complexo, se torna fundamental o papel do marketing na construção de um relacionamento que culmine na lealdade do cliente. Conquistar novos clientes envolve um custo muito maior do que reter clientes já existentes (ZEITHAML et al., 1996). Por isso, a importância do estudo da manutenção de clientes para as seguradoras, sendo relevante a pesquisa sobre o tema da lealdade de consumidores de seguros.

A compreensão de como ou por que um consumidor desenvolve um sentimento de lealdade continua a ser uma questão fundamental nos dias de hoje e é determinante para o sucesso de longo prazo de uma seguradora de automóvel. Desta forma, é essencial entender as razões que influenciam os consumidores no momento de avaliação das alternativas e de tomada de decisão no processo de contratação de seguros, aprofundando os estudos sobre comportamento do consumidor, fidelização e retenção de clientes.

\section{2 \\ Objetivos}

O propósito deste estudo é avaliar as relações entre os determinantes da lealdade de clientes no mercado de seguros de automóveis. Serão analisados os efeitos de diversos antecedentes (satisfação, custo de troca, atratividade das alternativas e confiança) e seus impactos na lealdade de clientes de seguros de automóvel.

A partir de estudos anteriores (PICÓN et al., 2014; AURIER e N'GOALA, 2010) o estudo também tem como objetivo propor um novo modelo para o entendimento das relações entre os determinantes da lealdade na indústria de seguros de automóveis. 


\section{3 \\ Relevância do Estudo}

A atividade de seguros movimenta $\mathrm{R} \$ 360$ bilhões por ano, representando 3.8\% do PIB nacional. De acordo com a SUSEP, dentro do seguro de danos, o seguro de automóvel representa $50 \%$ do total de prêmios emitidos contendo cerca de 5,5 milhões apólices de automóveis contratadas em todas as regiões do país. Atraídas por este grande volume de negócios, diversas seguradoras operam neste ramo de seguro gerando uma concorrência acirrada. Atualmente, mais de 10 companhias trabalham com seguros de automóvel.

Essa concorrência diminui a margem de lucros das seguradoras, dificultando o potencial de crescimento da carteira e torna o segurado mais exigente com o nível de serviço prestado. Para enfrentar os desafios, as empresas investem para tentar entender melhor os seus clientes para assim desenvolverem estratégias para mantê-los fiéis.

Assim, compreender melhor as relações entre antecedentes da lealdade no mercado de seguros de automóvel e como elas impactam a lealdade dos segurados pode ajudar as seguradoras a aumentarem o valor da sua base de clientes.

O presente estudo busca contribuir para a literatura aprofundando o conhecimento das características e particularidades dos clientes do mercado de seguros de automóvel, no contexto brasileiro, adaptando o modelo desenvolvido por Picón et al. (2014) que analisa a lealdade dos considerando a relação entre a satisfação, custo da mudança, atratividade das alternativas, e incorporando o construto de confiança, do modelo de Aurier e N'Goala (2010).

\section{4}

\section{Delimitação do estudo}

O estudo é delimitado a pessoas residentes no Brasil que utilizam ou já utilizaram veículo com seguro de automóvel contratado nos últimos dois anos anteriores ao momento da pesquisa. Esse período foi estipulado para que os respondentes tivessem uma opinião clara sobre sua seguradora de automóvel e pudessem oferecer respostas mais precisas. O estudo concentrou-se em seguros de automóvel não analisando outros tipos de seguros. 


\section{5 \\ Organização do Estudo}

Essa dissertação se divide em cinco capítulos. O primeiro capítulo apresenta os objetivos da pesquisa e destaca sua relevância dentro do contexto do estudo da lealdade de clientes no mercado de seguros de automóvel.

O segundo capítulo descreve a revisão da literatura sobre o tema da lealdade do cliente, dando ênfase no estudo da lealdade de clientes no mercado de seguros de automóvel. Esta etapa termina com a apresentação do modelo proposto por este presente estudo e as hipóteses de pesquisa sugeridas.

O capítulo três detalha a metodologia utilizada, definindo o tipo de pesquisa, a população de interesse, o processo de amostragem, os procedimentos para a elaboração do instrumento de pesquisa, o procedimento de coleta de dados, os métodos empregados na análise dos dados e as limitações do método.

O capítulo quatro apresenta os resultados do estudo. É realizado o teste dos modelos de mensuração e estrutural propostos, verificação das hipóteses de pesquisa e, então, discutidas as relações entre os construtos estudados.

O capítulo cinco conclui o trabalho, apresentando suas principais conclusões e contribuições de forma resumida. Nessa etapa são avaliadas as limitações do estudo e sugeridas novas pesquisas. 


\section{2 \\ Referencial Teórico}

Este capítulo apresenta o referencial teórico utilizado no estudo. A partir de pesquisas em artigos científicos, teses e dissertações, é feita uma revisão de tópicos relevantes da literatura referentes a conceitos de lealdade do consumidor.

\section{1}

\section{Relevância da lealdade no contexto organizacional}

A lealdade do consumidor é um tema relevante na literatura de marketing sendo um assunto estudado desde a década de 1950 (MCCONNELL, 1968). Os pesquisadores buscam contribuir no desenvolvimento de uma vantagem competitiva sustentável, onde as organizações almejam aumentar sua rentabilidade por meio da lealdade. Desta maneira, o conceito de lealdade pode se equiparar, muitas vezes, com o conceito de marketing de relacionamento, tendo em vista que a lealdade envolve a atração, a manutenção e o aumento da interação entre o consumidor e a marca (SHETH e PARK, 1974).

Segundo autores como Dick e Basu (1994) e Oliver $(1997,199)$, as consequências da lealdade são principalmente a propaganda boca a boca positiva e a resistência contra iniciativas de prospecção de concorrentes, além da maior frequência de recompra e uma maior rentabilidade dos lucros em função do aumento do valor do cliente ao longo do tempo (lifetime value). Reichheld e Sasser (1990) e Gremler e Brown (1999) verificaram empiricamente que quanto mais tempo uma marca mantém um cliente, maior será o lucro gerado pelo mesmo.

Sharp e Sharp (1997) e Dubé e Maute (1998) afirmaram em seus trabalhos que a lealdade se torna mais importante em mercados onde a concorrência é mais agressiva. Em mercados maduros, onde a disputa pelo marketshare é mais intensa, é mais difícil alcançar um crescimento expressivo, por isso se faz necessário buscar a retenção do cliente.

Por meio de um estudo empírico, Reichheld e Sasser (1990) constataram que reter $5 \%$ dos clientes que podem eventualmente migrar para a concorrência permitiria a duplicação dos lucros da empresa. Paralelamente, conquistar novos 
consumidores não é fácil e exige investimento de recursos que aumentam o custo de venda como, por exemplo, a alocação de recursos em programas de incentivo e bonificação dos vendedores, publicidade e custos gerais de prospecção. Os autores afirmam também que muitas empresas aplicam recursos para captar novos clientes, mas não fazem o mesmo esforço para criar um relacionamento de longo prazo capaz de reter os clientes atuais.

Apesar da busca da lealdade ser necessária para a sobrevivência das organizações, ela também é um desafio de entendimento e aplicação para os gestores e executivos de marketing. Medir o impacto de programas de lealdade ou de recuperação de falhas no relacionamento com clientes não é uma questão trivial (DUBÉ E MAUTE, 1998; REINARTZ e KUMAR, 2000; UNCLES, DOWNLING e HAMMOND, 2003). Outro desafio é determinar o custo de perda de um cliente, que na maioria das vezes não é conhecido pela empresa e por isso muitas vezes não é nem contabilizado como perda em seus resultados (UNCLES, DOWNLING e HAMMOND, 2003).

\section{2 \\ Lealdade}

Os pesquisadores do tema (DAY, 1969; JACOBY e KYNER, 1973; DICK e BASU, 1994; GREMLER e BROWN, 1999; OLIVER 1997, 1999, HART et al. 1999) definem o conceito da lealdade por meio três abordagens distintas: comportamental, atitudinal e integrada. A abordagem comportamental analisa a repetição de compra de um cliente ao longo do tempo. Nessa visão, a fidelidade do consumidor é medida simplesmente pelo comportamento de compra constante. A lealdade atitudinal envolve também aspectos psicológicos e emocionais dos consumidores. Leva em consideração a preferência e boa vontade de um cliente com relação a uma marca. Por sua vez, a integrada possui enfoque em características comportamentais e atitudinais sendo então uma combinação dos dois enfoques anteriores (VALVI, FRAGKOS, 2012).

\subsection{1}

\section{Lealdade Comportamental}

Estudos pioneiros, que em geral eram baseados em segmentos de bens duráveis, estudavam a lealdade principalmente como um comportamento de recompra observável (UNCLES, DOWLING e HAMMOND, 2003). Bastava apenas analisar o cliente vendo seu histórico de compras para mensurar sua 
lealdade com a marca (CUNNINGHAM, 1956; TUCKER; 1964; KAHN, KALWANI e MORRINSON, 1986).

Neste caso, a lealdade era um reflexo da proporção de compras (CUNNINGHAM, 1956), sequência de compras (KAHN, KALWANI e MORRISON, 1986), gasto médio por compra, penetração, longevidade, volume, frequência de compras e técnicas estocásticas descritivas de compras passadas (JACOBY e KYNER, 1973; UNLCES, DOWLING e HAMMOND, 2003).

Os autores como Andrew Ehrenberg, Mark Uncles, Grahame Downling defendem a utilização do modelo de lealdade comportamental e indicam a existência de uma abundância de dados empíricos que suportam esta perspectiva de considerar este método como a melhor forma de se medir a lealdade.

Produtos ou serviços que apresentam maior frequência de compras, como produtos de higiene e limpeza, restaurantes fast food, ou companhias aéreas, possuem uma maior disponibilidade de informação, permitindo uma análise mais confiável de dados transacionais. Por esta razão, é mais vantajoso o uso de medidas comportamentais. A escolha, de modo geral, faz parte da rotina do consumidor, portanto existe um baixo grau de envolvimento com o produto/serviço comprado. O cliente não enxerga a empresa dentro do seu conjunto de valores simbólicos (UNCLES, DOWLING e HAMMOND, 2003).

Outra vantagem que leva os pesquisadores a utilizarem medidas comportamentais se deve ao fato de consumidores também poderem apresentar lealdade a múltiplas marcas (SHETH e PARK, 1974; UNCLES, DOWNLING e HAMMOND, 2003). Por causa da acirrada concorrência, existe uma grande oferta de produtos e serviços com qualidade homogênea no mercado. Ocorre então um desgaste da lealdade, particularmente quando entendida como a compra repetida de uma mesma oferta (YIM e KANNAM, 1999). Uncles, Downling e Hammond (2003) afirmam que o resultado da grande oferta de produtos de uma mesma categoria, com padrão similar de qualidade e pouca diferenciação entre si seria a causa da lealdade a múltiplas marcas.

\subsection{2}

\section{Lealdade Atitudinal}

Critérios comportamentais utilizados para medir a lealdade tal como a repetição de compra e o volume total de vendas são debatidos por alguns autores que criticam estas medidas por refletirem uma visão estreita do relacionamento entre empresas e clientes (OLIVER, 1997). Fatores situacionais, 
como a falta de recursos, podem resultar no baixo grau de repetição de compra de um produto ou serviço, por exemplo. De antemão, a repetição de compras pode não representar uma preferência e sim ser fruto de uma inércia, de um alto custo de troca ou até mesmo uma indiferença em relação aos demais produtos ou serviços ofertados pelos concorrentes. Segundo Jaboby e Kynner (1973), a desvantagem do uso de parâmetros operacionais é o foco nos resultados do processo de escolha, desprezando a importância dos fatores que influenciam nesse processo.

As medidas comportamentais, quando avaliadas isoladamente, sem o estudo de outras variáveis psicológicas, oferecem um poder reduzido de análise do comportamento do consumidor, mesmo estando baseadas em indicadores confiáveis e detalhados de compra. Não se pode distinguir os consumidores realmente comprometidos e envolvidos no processo de compra avaliando-se apenas ao seu histórico de compra (DAY, 1969; JACOBY e CHESTNUT, 1978).

$\mathrm{Na}$ literatura, a perspectiva ou dimensão da "atitude" no construto da lealdade foi proposta pela primeira vez por Day (1969). Em seu estudo, a utilização dos critérios atitudinais na medição de lealdade foi defendida para auxiliar a segmentação de clientes que apresentavam alta taxa de recompra. Sobre a atitude, Ajzen (1993) define como a disposição do indivíduo em reagir de um modo favorável ou não em relação a um objeto, comportamento, pessoa, instituição, evento ou qualquer outro aspecto relevante para o conjunto de valores do indivíduo.

Jacoby (1971) em seu estudo que identifica a lealdade a múltiplas marcas também defendeu esta abordagem. Sua pesquisa considerava que a partir do momento que um grupo limitado de empresas oferecesse produtos ou serviços com qualidade equivalente ou similar, o consumidor facilmente substituiria uma marca por outra concorrente. Só era possível a lealdade a uma só empresa se na cabeça do consumidor não houvesse nenhuma possibilidade de consumir um outro produto diferente que não fosse o da sua marca de sua preferência.

Aspectos comportamentais e atitudinais foram aos poucos sendo incluídos no construto da lealdade representando assim uma nova perspectiva de pensamentos da literatura de marketing, conforme Day (1969), Jacoby e Kyner (1973), Dick e Basu (1994) e Oliver (1997, 1999).

Jacoby e Kyner (1973) elaboraram um modelo de lealdade que engloba tanto componentes comportamentais como os atitudinais. O autor define lealdade em função de seis condições necessárias e coletivamente suficientes: lealdade à marca é a ação comportamental (1), intencional (2), expressa no tempo (3), por uma unidade de compra (4), em relação a um conjunto de marcas 
alternativas (5) e em função de processos psicológicos (6) (JACOBY e KYNER, 1973).

Desta maneira, dentro dos modelos atitudinais a lealdade do cliente é aquela na qual o indivíduo possui um vínculo afetivo com a marca. Por outro lado, os clientes com lealdade espúria seriam aqueles que compram por um longo período de tempo por rotina, conveniência ou por falta de alternativas (HART et al 1999) porém sem desenvolver nenhum vínculo ou relacionamento com a empresa (BUTCHER et al 2001), podendo, às vezes, nem serem clientes rentáveis (REINARTZ e KUMAR, 2000).

\subsection{3}

\section{Modelo integrado de Dick e Basu (1994)}

Dick e Basu (1994) aplicaram um modelo integrado, onde a lealdade é a combinação entre a repetição de compra do cliente e a sua atitude relativa, baseando-se nos trabalhos de Day (1969) e Jacoby e Kyner (1973).

O trabalho dos autores teve como principal destaque a inclusão do conceito de atitude relativa. Os dois autores consideram vantajoso comparar as marcas consideradas importantes pelos clientes dentro de uma situação de consumo por meio da previsão de comportamentos dos indivíduos.

O conceito de atitude relativa pode fornecer uma previsão mais precisa do comportamento de recompra do que uma atitude com relação a uma marca tomada isoladamente. A intensidade atitudinal e o grau de diferenciação formam duas dimensões que fundamentam a atitude relativa de um cliente com relação a um objeto (DICK e BASU, 1994).

Os mesmos autores ao correlacionarem atitude relativa e repetição de compra, identificam quatro tipos de lealdade: verdadeira, latente, espúria e ausência de lealdade. A lealdade verdadeira ocorre quando o cliente apresenta uma alta atitude relativa em relação à marca e um alto comportamento de recompra. A lealdade latente ocorre quando um cliente apresenta um comportamento baixo de recompra, todavia possui uma forte preferência ou atitude em relação à marca. A lealdade espúria ocorre quando o cliente apresenta um comportamento de recompra, mas não considera que a marca possui diferenciais comparado com seus concorrentes. A recompra periódica pode ocorrer em situações como monopólios onde não há alternativas ou em situações que a escolha é realizada com base em hábitos passados.

A ausência de lealdade ocorre quando os consumidores não diferenciam as marcas e apresentam baixo comportamento de recompra. O estudo proposto 
pelos autores indica que os antecedentes cognitivos, afetivos e conativos influenciam a atitude relativa.

Os antecedentes cognitivos são formados pela acessibilidade, confiança, centralidade e clareza. Acessibilidade é a facilidade com que uma atitude é recuperada pela memória. Confiança é o nível de certeza que acompanha uma atitude. Centralidade é o nível de aderência do conjunto de valores de um consumidor com a atitude em relação a uma marca. Por fim, a clareza ocorre quando o consumidor considera que sua atitude é a única possível dentre as alternativas possíveis.

Antecedentes afetivos são compostos pelas emoções, estado emocional ou de humor, afeto primário e pela satisfação. As emoções levam o indivíduo a voltar sua atenção em coisas específicas sendo capaz de alterar seu comportamento. O estado emocional ou de humor influencia a lealdade através do seu impacto na acessibilidade. Ou seja, relaciona seu estado emocional atual com suas experiências relacionadas em sua memória. Afeto primário é uma resposta imediata estimulada pela presença de uma atitude que influencia o nível de relação entre atitude e o comportamento independente dos componentes cognitivos. Por último, a satisfação é uma avaliação da marca feita pelo cliente levando em consideração sua necessidade e expectativas (OLIVER, 1997).

Antecedentes conativos são formados pelo custo de troca, custos afundados e expectativa. Custo de troca é o esforço e desprendimento de recursos quando se deseja mudar de fornecedor. Custos afundados não devem ser considerados na análise de novos investimentos pois são custos que já foram incorridos e não podem ser recuperados. Expectativa reflete o ajuste entre as ofertas presentes e futuras do mercado e as necessidades e desejos dos consumidores.

Quando favoráveis a uma marca, os antecedentes cognitivos, afetivos e conativos se tornam um diferencial perante os concorrentes e estimulam que os clientes apresentem uma atitude relativa mais positiva (DICK e BASU, 1994).

\subsection{4}

\section{Modelo integrado de Oliver (1997)}

Oliver (1997) segue a estrutura atitudinal e propõe a noção de comprometimento em sua definição de lealdade. O autor define a lealdade como um comprometimento em comprar novamente um mesmo produto ou serviço de uma determinada marca no futuro, apesar das influências situacionais e dos 
esforços da concorrência que buscam mudar seu comportamento de consumo (OLIVER, 1997). Apresentando um modelo na qual a lealdade é um processo dinâmico onde não é necessário que os três antecedentes de atitude ocorram ao mesmo tempo para que a lealdade exista, Oliver (1997) leva em consideração o comportamento de repetição de compra, o comprometimento representado pela influência dos aspectos psicológicos, fatores situacionais e as tentativas de persuasão da concorrência no processo de formação da lealdade do consumidor.

Baseando-se no trabalho de Jacoby e Chestnut (1978), Oliver (1997) também utilizou a cognição, afeição e conação em seu estudo da lealdade. Em seu modelo, o autor afirma que existem diferentes tipos de estágios da lealdade que geralmente são sequenciais, no sentido de que a lealdade conativa pressupõe a existência da lealdade afetiva que pressupõe a existência da lealdade cognitiva. Por fim, o autor sugere a existência de mais um estágio que é a lealdade ativa que nada mais é do que a transformação de uma intenção de recompra em comportamento por meio de uma ação concreta de consumo.

Oliver (1997) indica alguns obstáculos à lealdade, como particularidades individuais e certos aspectos relacionados à natureza do consumo que são contrários à lealdade. Dentre estes aspectos, destacam-se a busca por variedade e experimentação, a mudança das necessidades do consumidor, desistência da categoria de produto ou serviço representada pela marca preferida e a lealdade a mais de uma marca. Outro fator que dificulta a lealdade do cliente são os incentivos de troca que decorrem basicamente do forte poder de persuasão que a concorrência exerce sobre o consumidor. Para o autor, todas as etapas da lealdade possuem vulnerabilidades e forças de sustentação que podem impedir o seu progresso para a etapa posterior ou até conduzir o consumidor à deslealdade.

\section{3 \\ Satisfação}

A satisfação é definida por Oliver $(1997,1999)$ como a percepção do consumidor de que um desejo, necessidade ou objetivo foi satisfeito de forma suficiente por meio de uma experiência de consumo. Para Chen e Wang (2009), a satisfação do consumidor é um tipo de avaliação entre a expectativa e percepção de desempenho de um determinado produto ou serviço. A resposta do consumidor a essas comparações entre desempenho e expectativa pode ser entendida então como a satisfação do cliente. Conforme Oliver (1997), 
satisfação é a resposta-realizada do consumidor. É um julgamento de que um produto/serviço oferece um nível prazeroso de consumo. Fornell (1992), também define satisfação como uma avaliação geral do desempenho com base em todas as experiências anteriores.

Os autores Garbarino e Johnson (1999) afirmam que existem dois tipos de satisfação. A primeira seria a satisfação cumulativa, que é um conjunto de avaliações das experiências de consumo feitas ao longo do tempo. A outra seria a satisfação de transações específicas, que é entendida por uma avaliação feita imediatamente após o consumo sendo realizado então um julgamento imediato ou uma reação afetiva à mais recente experiência com a marca (GARBARINO e JOHSON, 1999).

Se as experiências positivas do cliente excederem suas expectativas, provavelmente os clientes estarão mais satisfeitos. Assim, a satisfação do cliente pode ser definida como uma avaliação de que sua experiência foi pelo menos tão boa quanto supostamente era esperado (HUNT, 1977).

\section{4 \\ Custo de Troca}

Porter (1980) afirma que custo de troca é a percepção da magnitude ou grandeza dos custos adicionais requeridos para terminar o relacionamento corrente e optar por uma alternativa concorrente. Para os autores Morgan e Hunt (1994), os custos de troca são identificados como um fator que contribui para a manutenção do relacionamento entre a empresa e o consumidor. Todavia, para esses autores, os custos de troca possuem natureza meramente econômica.

Outros autores, como Sharma (2003), afirmam que os custos de troca podem apresentar aspectos psicológicos e emocionais. Um exemplo é o vínculo de confiança construído ao longo do tempo com uma empresa, que cria uma barreira que não é financeira. Assim, esse efeito psicológico atua como um custo, mesmo se o desempenho do serviço ou do produto seja menor que o satisfatório. A troca de fornecedor envolveria também outros esforços não monetários, como tempo e reflexão.

Para Wang et al (2001), a definição de custo de troca é a percepção do tempo, dinheiro e esforço despendido necessário para que o consumidor efetue a mudança de uma empresa para uma outra. Esse custo pode envolver também um comprometimento afetivo, que pode representar uma barreira psicológica e emocional à mudança, e um comprometimento calculado, no qual se apoiam os argumentos mais racionais da transição (NESSET, HELGESEN, 2014). De forma 
ampla, a maioria dos custos de troca é formado por questões econômicas e por questões mais subjetivas como, por exemplo, a natureza do produto, características dos consumidores, custos de pesquisa, aprendizagem, mudanças comportamentais e estratégicas (NESSET, HELGESEN, 2014, WANG et al., 2001).

Empresas podem desencorajar clientes a romper o relacionamento através da criação de custos de trocas, aumentando as dificuldades que o processo de mudança implica. A literatura reconhece o custo de troca como uma construção multidimensional (BARROSO e PICÓN, 2012). Portanto, a natureza desses custos (relacional, financeira, psicológica ou associada ao tempo que o processo de mudança exige) pode variar dependendo do setor ou da indústria analisada.

Burnham et al. (2003) abordam a lealdade passiva gerada pelos custos de mudança para estabelecer uma tipologia, antecedentes e consequências dos custos de troca. Os autores sugerem oito tipos: custos de risco econômico; custos de avaliação; custos de aprendizagem; custos de inicialização; custos de perda de benefícios; custos de perdas monetárias; custos de perda de relacionamento pessoal; e custos de perda de relacionamento com a marca.

Os oito tipos podem ser divididos em três grupos. O primeiro grupo identificado como custos de mudança de procedimento ou processual envolvem esforço e perda de tempo e é composto por risco econômico, avaliação, aprendizagem e inicialização; O segundo grupo designado é associado à perda quantificável de recursos financeiros e por isso é composto pelos custos de mudança de perda monetária e de benefícios. Por fim, o terceiro grupo é composto pela perda de relacionamento pessoal e de perda de relacionamento com a marca e correspondem aos custos de mudanças relacionais que envolvem desconforto psicológico ou emocional devido à perda de identidade e à ruptura de laços (BURNHAM et al., 2003).

\section{5}

\section{Atratividade das alternativas}

A relevância de uma alternativa concorrente tem sido muito pesquisada em estudos sobre a tomada de decisão do consumidor e sobre relações interpessoais (HUNG 2006). A "teoria do arrependimento" (BELL, 1982; LOOMES e SUGDEN, 1982) identificou que indivíduos podem sentir arrependimento ou alegria diante do resultado de uma decisão. A pessoa se arrepende se o resultado obtido foi pior que a alternativa concorrente e se sente feliz quando atinge um resultado melhor. A teoria discute basicamente a 
probabilidade associada à escolha que pode ser de conforto ou arrependimento, fazendo com que o valor da decisão escolhida dependa dos itens simultaneamente excluídos. Se as opções preteridas forem de grande atratividade, o valor da escolha e as probabilidades de arrependimento se intensificam.

\section{6}

\section{Confiança}

Para Morgan e Hunt (1994), o conceito de confiança pode ser definido como a necessidade ou vontade de poder contar com um outro indivíduo parceiro no qual se deposita a confiança. Já para Rotter (1967) a confiança é uma expectativa individual de que a palavra do outro é confiável (ALTMAN e TAYLOR, 1973; DWYER e LAGACE, 1986; LARZELERE e HUSTON, 1980; ROTTER, 1967).

Segundo Poppo e Schepker (2010), a confiança do cliente é fundamental para a sobrevivência das empresas. Outros autores como Mayer, Davis e Schoorman (1995) definem confiança como a disposição de um indivíduo a ficar exposto ou vulnerável às ações de outro com base na expectativa de que a outra parte cumprirá uma ação considerada importante.

Uma organização que é percebida como detentora de benevolência, competência e integridade é considerada digna de confiança. O cliente avalia o desempenho de uma empresa após uma experiência de consumo e o seu resultado pode reforçar ou diminuir a sua confiança. Será considerada confiável uma empresa que possuir uma elevada percepção das três dimensões (MAYER et al., 1995). Para Mayer et al. (1995), a confiança decorre da benevolência, da competência e da integridade, mas essas dimensões são independentes e nem sempre caminham na mesma direção.

Segundo Mayer et al. (1995) a benevolência corresponde a uma percepção positiva onde um indivíduo ou organização deseja fazer o bem sem interesse de um ganho próprio. A benevolência está relacionada à ausência de oportunismo e consiste em acreditar que o outro não irá prejudicá-lo mesmo tendo uma oportunidade de fazê-lo (MAYER et al., 1995). Os autores ressaltam também que a benevolência sozinha não é suficiente para a construção da confiança, é preciso que ela esteja combinada com a competência e com a integridade

Para Sirdeshmukh, Singh e Sabol (2002), competência é uma condição necessária para o desenvolvimento da confiança e se baseia na expectativa de 
um desempenho satisfatório e qualificado de uma outra parte. Segundo Mayer et al. (1995), a competência é a crença do consumidor na capacidade de um provedor ao adquirir um produto ou serviço.

A integridade ou honestidade se refere às percepções dos indivíduos de que a outra parte irá aderir ao conjunto de princípios e regras acordados previamente (MAYER et al., 1995). Murphy, Laczniak e Wood (2007) apontam que a integridade está relacionada à adesão a um código moral. A integridade é um fator importante, pois nas relações entre indivíduos existem princípios e regras implícitas que, caso não sejam cumpridas, podem romper o relacionamento. Ou seja, para Mayer et al. (1995) a integridade é a avaliação da disposição do outro em cumprir promessas, sendo imprescindível na construção da confiança.

\section{7 \\ Modelo Conceitual e Hipóteses}

\subsection{1 \\ Satisfação e Lealdade}

$\mathrm{Na}$ literatura, a satisfação é o antecedente da lealdade mais estudado e, na grande maioria, as pesquisas apontam uma relação positiva significante entre satisfação e lealdade (VALVI, FRAGKOS, 2012). Todavia, a satisfação não se converte obrigatoriamente em lealdade, apesar de consumidores leais serem usualmente satisfeitos (OLIVER, 1999).

Outros estudos apoiam a conclusão de que a satisfação do cliente afeta positivamente a lealdade dos clientes. Segundo Cronin e Taylor (1992), a satisfação é considerada um determinante fundamental da lealdade do cliente. Os resultados nos estudos feitos pelos autores Kantsperger e Kunz (2010) demonstraram uma relação positiva entre a satisfação do cliente e a lealdade.

Para Chen e Wang (2009), a satisfação do consumidor é um tipo de avaliação entre a expectativa e a percepção de desempenho da marca. Consequentemente, a avaliação positiva do cliente influencia no seu julgamento de continuar ou não com uma empresa. O resultado é que clientes satisfeitos possuem uma maior probabilidade de recompra, são clientes com uma menor sensibilidade aos preços e usualmente possuem um maior envolvimento com a marca através de recomendações boca-a-boca positivas (Chen e Wang, 2009).

Geralmente, a satisfação é considerada um antecedente importante da lealdade na indústria de serviços (HAGHIGHI et al. 2012, HAU e THUY 2012 e SULTAN e WONG 2013). Um estudo realizado por de Sultam e Wong (2013), 
confirmou que clientes satisfeitos desenvolvem preferência por uma determinada seguradora na qual oferece serviços satisfatórios. O nível percebido de satisfação do cliente explicou uma quantidade considerável de variação de preferência de marca. Picón et al. (2014) afirmam que uma das formas de se elevar a lealdade do cliente é por meio do aumento da satisfação do cliente.

Assim, considera-se a hipótese:

\section{H1. A satisfação possui um efeito direto e positivo sobre a lealdade.}

\subsection{2}

\section{Satisfação, Custo de troca e Lealdade}

Oliver (1999) sugere que a satisfação é um passo necessário no processo de construção da lealdade, mas que esta variável se torna menos significativa quando outros mecanismos (tais como vínculos sociais e pessoais, a existência de obrigações contratuais, etc.) influenciam esta lealdade. Todos esses fatores criam custos de mudança que fortalecem a retenção de clientes. Estudos mostram como o custo de troca desempenha um papel importante no que diz respeito à satisfação ao explicar a lealdade (PATTERSON e SMITH, 2003; TSAI, HUANG, JAW, e CHEN, 2006).

Ngobo (2004) defende a visão de que a satisfação do cliente determina o nível da percepção do custo de troca. O autor afirma que a satisfação do cliente tem um efeito positivo sobre os custos de troca, aumentando assim a percepção de desvantagem do cliente na troca de um fornecedor. Por isso, quanto maior a satisfação geral, maiores serão os custos de troca ou maior será a expectativa de perda numa eventual mudança de marca feita pelo cliente. Ou seja, o consumidor percebe maiores dificuldades de romper o relacionamento corrente ou associa maior inutilidade na troca de fornecedores quando ele possui um alto nível de satisfação com sua empresa atual (NGOBO, 2004). Através da criação de custos de mudança, as empresas podem desencorajar os clientes a mudarem para um concorrente. (BARROSO e PICÓN, 2012).

A natureza desses custos (relacional, monetária, psicológica ou associada ao tempo que o processo de mudança assume) pode ser muito diferente dependendo do setor ou da indústria. Em seu estudo sobre a lealdade no mercado de seguros, os autores Picón et al. (2014) identificaram que a criação do custo de troca é uma das formas de se elevar a lealdade. O cliente com um alto custo percebido de troca tende a manter o relacionamento com a seguradora atual. 
Custos de troca afetam a lealdade dificultando a mudança para outro fornecedor. Portanto, esta pesquisa investiga as hipóteses:

\section{H2. A satisfação possui um efeito direto e positivo sobre o custo de troca}

H3. O custo de troca possui um efeito direto e positivo sobre a lealdade.

\subsection{3}

\section{Satisfação, Atratividade das Alternativas e Lealdade.}

A atratividade das alternativas aparece na literatura como um fator que motiva e favorece a mudança para uma marca concorrente. Caso contrário, um mercado com baixa concorrência e sem muita oferta de produtos similares, a baixa atratividade das alternativas aumenta a lealdade à marca habitual. A definição do nível da atratividade das alternativas disponível é a probabilidade do cliente obter satisfação através de uma marca alternativa (BANSAL et al., 2005). Portanto, aqueles clientes satisfeitos com sua marca habitual perceberão que as outras ofertas que existem no mercado são menos atraentes. Os clientes avaliarão comparativamente, por meio de uma análise custo-benefício, de tal forma que se o cliente perceber que o provedor existente é superior, o benefício da mudança será menor.

No entanto, a empresa não controla esta variável em algumas situações, uma vez que o cliente pode decidir permanecer na relação dada a estrutura de mercado, ou porque, embora existam ofertas alternativas, estas ofertas estão fora da gama de opções do cliente. Assim, se os clientes não estão cientes da atratividade das alternativas, ou simplesmente não percebem qualquer oferta alternativa como sendo mais atraente do que o provedor atual, eles são mais propensos a permanecer no relacionamento (PATTERSON e SMITH, 2003).

Portanto, as empresas que tentam se diferenciar de seus concorrentes, oferecendo preços mais competitivos, melhor qualidade de serviço, melhor atendimento ao cliente e assim por diante - aumentando o nível de satisfação estão trabalhando para a redução da atratividade das alternativas (ANTÓN et al., 2007) e, portanto, estimulam a lealdade dos clientes.

Assim, duas hipóteses são propostas:

H4. A satisfação possui um efeito direto e negativo sobre a atratividade das alternativas. 
H5. A atratividade das alternativas possui um efeito direto e negativo sobre a lealdade.

\subsection{4}

\section{Satisfação, Confiança e Lealdade}

A confiança desempenha um papel fundamental na construção de um relacionamento de longo prazo entre a marca e o cliente. Chaudhuri e Holbrook (2001) definem a confiança na marca como a disposição do consumidor de confiar na capacidade da marca para desempenhar sua função declarada. Em geral, a confiança envolve dois parceiros numa relação de troca. A confiança na marca se baseia na percepção de que a empresa é confiável e responsável pelo interesse e pelo bem-estar do usuário.

Normalmente, um cliente insatisfeito gera um boca-a-boca negativo. Por outro lado, um cliente satisfeito pode gerar um boca-a-boca positivo e assim um aumento no nível de confiança da marca. Confiança na marca leva a lealdade, porque a confiança cria relações de troca que são valorizadas. Uma consequência importante da confiança é um relacionamento duradouro. Pesquisadores que examinaram empiricamente a relação entre confiança e lealdade identificaram que a confiança é um fator determinante da fidelidade à marca (MORGAN e HUNT, 1994; CHAUDHURI e HOLBROOK, 2001; SIRDESHMUKH et al., 2002)

Assim, as hipóteses são propostas:

H6. A satisfação possui um efeito direto e positivo sobre a confiança. H7. A confiança possui um efeito direto e positivo sobre a lealdade.

\subsection{5}

\section{Modelo Conceitual Proposto}

Para verificar as hipóteses indicadas anteriormente, foi empregado o modelo ilustrado na Figura 2.1, desenvolvido a partir de uma adaptação do modelo proposto por Picón et al. (2014) com a inclusão do construto confiança, utilizado no modelo de Aurier e N'Goala (2010). 


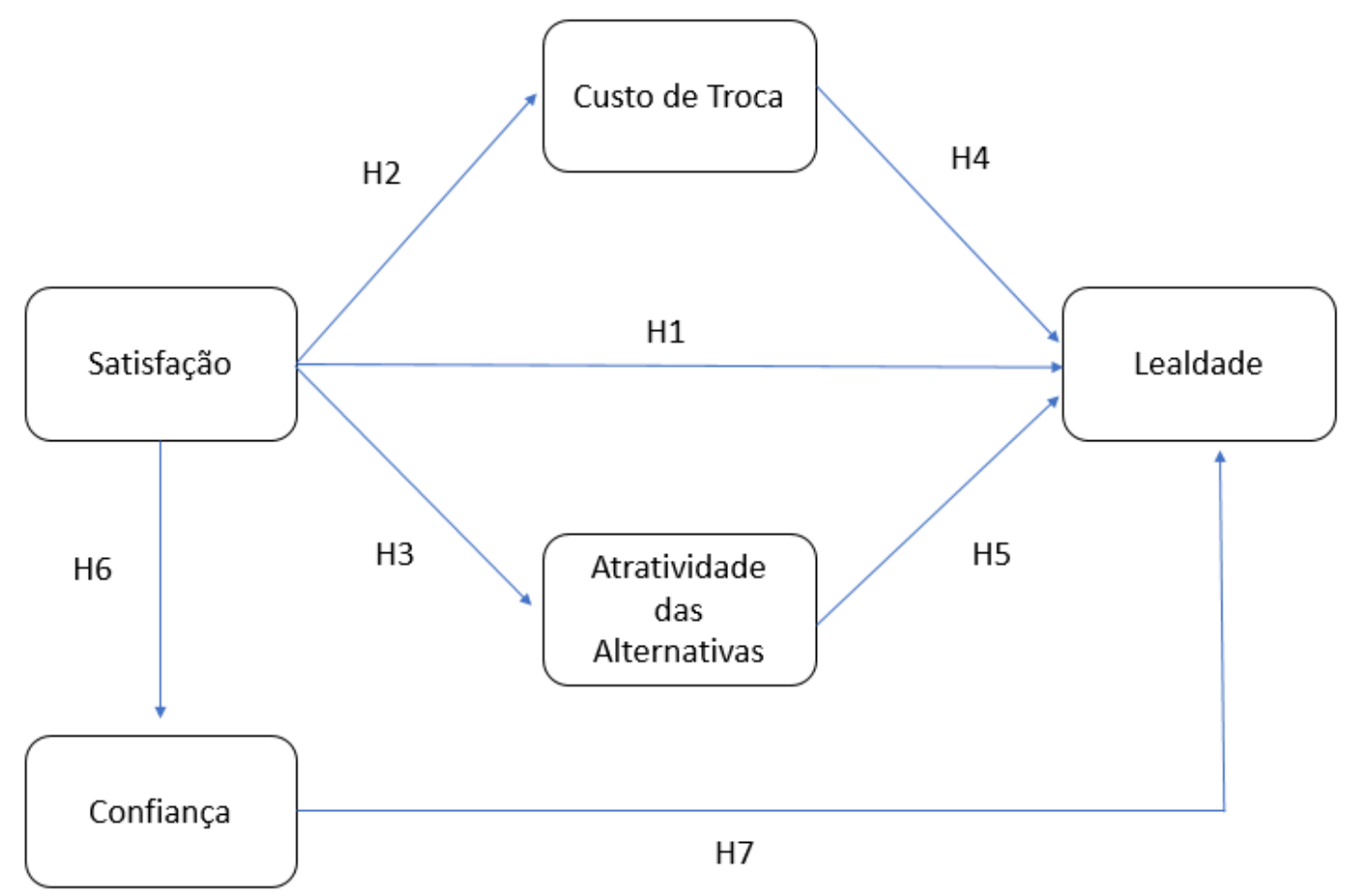

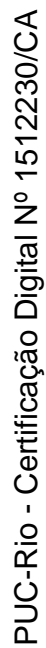

Figura 2.1: Modelo Conceitual Proposto

Fonte: Própria 


\section{3 \\ Metodologia}

Neste capítulo são apresentados os principais aspectos metodológicos, incluindo procedimentos utilizados na pesquisa para testar as hipóteses propostas na seção anterior. A seguir, serão descritos o tipo de pesquisa, escalas de mensuração de cada variável, o processo de amostragem, o método utilizado na coleta de dados, a análise dos dados e as limitações do método.

\section{1}

\section{Tipo de Pesquisa}

Com o objetivo de testar as hipóteses propostas no estudo, foi realizada uma cross-sectional survey (PARASURAMAN et al., 2006), por meio de questionários auto administrados via internet (AAKER et al., 2006), com uma amostra não probabilística da população de interesse.

Segundo Cooper e Schindler (2003), o instrumento survey é o questionário estruturado, constituído por diversas perguntas, onde as questões devem ser elaboradas com cuidado, pois nem sempre as respostas dos indivíduos coincidem com o que se deseja saber. O survey é a opção mais adequada quando se objetiva coletar dados primários com fins de investigação causal e generalização de resultados, além de permitir testar hipóteses envolvendo diversas variáveis que interagem entre si (COOPER e SCHINDLER, 2003). Os questionários foram distribuídos a indivíduos que possuem ou já possuíram seguro de automóvel contratado nos últimos 24 meses.

\section{2}

\section{Operacionalização e Definição das Variáveis}

O presente estudo faz uso de escalas já elaboradas e testadas pela literatura para a medição de todos os construtos envolvidos. O instrumento de pesquisa (Apêndice $A$ ) desenvolvido neste trabalho operacionaliza a medição dos seguintes construtos: satisfação, custo da mudança, atratividade das alternativas, confiança e lealdade do consumidor.

Baseado em pesquisas anteriores (PICÓN et al., 2014; AURIER e N'GOALA, 2010), para a mensuração das variáveis foi utilizada uma escala do 
tipo Likert de cinco pontos, variando entre "discordo totalmente" e "concordo totalmente". Essa escala demanda que os respondentes indiquem de 1 a 5 conforme a sua percepção do grau de concordância ou discordância com as afirmativas relacionadas a cada construto apresentado no questionário. Neste caso, 1 (um) significa a discordância total em relação a afirmativa, enquanto que 5 (cinco) significa que o participante concorda totalmente com a frase apresentada e o 3 é considerado neutro, "não concorda nem discorda".

\subsection{1}

\section{Definição Operacional das Variáveis}

Essa pesquisa foi elaborada a partir dos modelos propostos por Picón et al. (2014) e Aurier e N'Goala (2010). A seguir, o quadro 3.1 apresenta as escalas originais e traduzidas para medir cada construto, assim como os estudos dos quais essas escalas foram retiradas.

\section{Quadro 3.1: Definições operacionais das variáveis}

\begin{tabular}{|c|c|}
\hline \multicolumn{2}{|c|}{ Construto Satisfação - Referência: Picón et al. (2014) } \\
\hline Perguntas Originais & Perguntas Adaptadas para o Questionário \\
\hline 1. This company meets my needs. & $\begin{array}{l}\text { 1. Esta seguradora atende minhas } \\
\text { necessidades }\end{array}$ \\
\hline $\begin{array}{l}\text { 2. This company is as good as or } \\
\text { even better than other companies. }\end{array}$ & $\begin{array}{l}\text { 2. Esta seguradora é boa, ou até melhor } \\
\text { que as concorrentes. }\end{array}$ \\
\hline $\begin{array}{l}\text { 3. My claims or problems are } \\
\text { always dealt with quite well. }\end{array}$ & $\begin{array}{l}\text { 3. Minhas solicitações ou problemas são } \\
\text { sempre resolvidos de maneira adequada }\end{array}$ \\
\hline 4. This company is very competent. & 4. Esta seguradora é muito competente \\
\hline $\begin{array}{l}\text { 5. This company gives me the } \\
\text { service that I expect. }\end{array}$ & $\begin{array}{l}\text { 5. Esta seguradora me presta o serviço } \\
\text { que atende minhas expectativas. }\end{array}$ \\
\hline $\begin{array}{l}\text { 6. This company gives an excellent } \\
\text { service. }\end{array}$ & $\begin{array}{l}\text { 6. Esta seguradora me presta um } \\
\text { excelente serviço }\end{array}$ \\
\hline $\begin{array}{l}\text { 7. In general, my experience with } \\
\text { the company is positive }\end{array}$ & $\begin{array}{l}\text { 7. Em geral, minha experiência com a } \\
\text { seguradora é positiva }\end{array}$ \\
\hline \multicolumn{2}{|c|}{ Construto Custo de Troca - Referência: Picón et al. (2014) } \\
\hline Perguntas Originais & Perguntas Adaptadas para o Questionário \\
\hline $\begin{array}{l}\text { 1. I cannot afford the time to get the } \\
\text { information to evaluate other } \\
\text { insurance companies fully. }\end{array}$ & $\begin{array}{l}\text { 1. Eu não disponho de tempo para buscar } \\
\text { as informações das outras seguradoras } \\
\text { concorrentes necessárias para uma plena } \\
\text { avaliação da melhor escolha. }\end{array}$ \\
\hline $\begin{array}{l}\text { 2. I consider that it takes a lot time } \\
\text { and effort to get the information } \\
\text { needed to feel comfortable } \\
\text { evaluating } \text { new r insurance } \\
\text { companies. }\end{array}$ & $\begin{array}{l}\text { 2. Eu considero que é preciso muito tempo } \\
\text { e esforço para obter as informações das } \\
\text { outras seguradoras necessárias para me } \\
\text { sentir confortável na escolha da melhor } \\
\text { opção. }\end{array}$ \\
\hline
\end{tabular}




\begin{tabular}{|c|c|}
\hline $\begin{array}{l}\text { 3. Switching to a new insurance } \\
\text { company would involve some up- } \\
\text { front costs (set-up fees, } \\
\text { membership fees, deposits, etc.). }\end{array}$ & $\begin{array}{l}\text { 3. Mudar para uma outra seguradora } \\
\text { implicaria algum custo (tarifas, taxas de } \\
\text { adesão, depósitos, etc). }\end{array}$ \\
\hline $\begin{array}{l}\text { 4. In my opinion, it takes a lot of } \\
\text { money to pay for all of the costs } \\
\text { associated with switching insurance } \\
\text { companies. }\end{array}$ & $\begin{array}{l}\text { 4. Na minha opinião, é caro pagar por } \\
\text { todos os custos referentes a troca de uma } \\
\text { seguradora. }\end{array}$ \\
\hline $\begin{array}{l}\text { 5. Switching to a new company } \\
\text { would mean losing or replacing } \\
\text { points, credits, length of services, } \\
\text { and so on, that I have accumulated } \\
\text { with my insurance company. }\end{array}$ & $\begin{array}{l}\text { 5. Mudar para uma nova seguradora } \\
\text { significaria perder bônus, descontos, } \\
\text { créditos, quantidade de serviços e assim } \\
\text { por diante, que eu acumulei com minha } \\
\text { seguradora atual. }\end{array}$ \\
\hline $\begin{array}{l}\text { 6. I would lose a lot of credits, } \\
\text { accumulated points, and services } \\
\text { that I have already paid for, if I } \\
\text { switch to a new insurance company. }\end{array}$ & $\begin{array}{l}\text { 6. Eu perderia muitos créditos, bônus, } \\
\text { pontos acumulados e serviços que eu já } \\
\text { paguei, se eu mudar para uma nova } \\
\text { seguradora }\end{array}$ \\
\hline $\begin{array}{l}\text { 7. I will lose the benefits of being a } \\
\text { long-term customer if I leave my } \\
\text { insurance company. }\end{array}$ & $\begin{array}{l}\text { 7. Se eu trocar de seguradora, eu perderia } \\
\text { os benefícios de ser um cliente de longa } \\
\text { data. }\end{array}$ \\
\hline $\begin{array}{l}\text { 8. Switching insurance companies } \\
\text { involves an unpleasant sales } \\
\text { process. }\end{array}$ & $\begin{array}{l}\text { 8. Trocar de seguradora envolve um } \\
\text { processo de vendas desagradável }\end{array}$ \\
\hline $\begin{array}{l}\text { 9. There are a lot of formalities } \\
\text { involved in switching to a new } \\
\text { insurance company. }\end{array}$ & $\begin{array}{l}\text { 9. Existem muitas formalidades envolvidas } \\
\text { na troca para uma nova seguradora. }\end{array}$ \\
\hline $\begin{array}{l}\text { 10. I would miss working with the } \\
\text { people at my insurance company if I } \\
\text { switched providers. }\end{array}$ & $\begin{array}{l}\text { 10. Eu sentiria falta do relacionamento das } \\
\text { pessoas da minha seguradora atual se } \\
\text { trocasse por uma outra. }\end{array}$ \\
\hline $\begin{array}{l}\text { 11. I am more comfortable } \\
\text { interactingwith the peopleworking } \\
\text { formy insurance company than I } \\
\text { would be if I switched providers. }\end{array}$ & $\begin{array}{l}\text { 11. Eu me sinto mais confortável } \\
\text { interagindo com as pessoas que } \\
\text { trabalham na minha seguradora atual do } \\
\text { que seria se eu trocasse por uma } \\
\text { seguradora nova. }\end{array}$ \\
\hline $\begin{array}{l}\text { 12. I like talking to the people where } \\
\text { I get my service. }\end{array}$ & $\begin{array}{l}\text { 12. Eu gosto de conversar com as } \\
\text { pessoas das empresas que me prestam } \\
\text { serviços. }\end{array}$ \\
\hline $\begin{array}{l}\text { 13. Switching to a new insurance } \\
\text { company will probably involve } \\
\text { hidden costs/charges. }\end{array}$ & $\begin{array}{l}\text { 13. Trocar para uma nova seguradora } \\
\text { provavelmente envolverá custos/encargos } \\
\text { implícitos }\end{array}$ \\
\hline $\begin{array}{l}\text { 14. I am likely to end up with a bad } \\
\text { deal financially if I switch to a new } \\
\text { insurance company. }\end{array}$ & $\begin{array}{l}\text { 14. Provavelmente irei acabar com um } \\
\text { mau negócio financeiramente se eu mudar } \\
\text { para uma nova seguradora }\end{array}$ \\
\hline $\begin{array}{l}\text { 15. Trocar para uma nova } \\
\text { seguradora provavelmente resultará } \\
\text { em algum } \quad \text { aborrecimento } \\
\text { inesperado. }\end{array}$ & $\begin{array}{l}\text { 15. Switching to a new insurance company } \\
\text { will probably result in some unexpected } \\
\text { hassle. }\end{array}$ \\
\hline
\end{tabular}


Construto Atratividade das Alternativas - Referência: Picón et al. (2014)

\begin{tabular}{l}
\hline Perguntas Originais \\
1. I believe that another company \\
could benefit me more than my \\
current company in achieving my \\
aims.
\end{tabular}

2. I would feel more satisfied with the services of another company than I am with my current company.

3. In general, I believe that another company would be less costly than the current one.

4. I think that a new company would offer me a more complete range of services.
Perguntas Adaptadas para o Questionário

1. Eu acredito que uma outra seguradora me beneficiaria mais do que minha seguradora atual na consecução dos meus objetivos.

2. Eu me sentiria mais satisfeito com os serviços de outra seguradora do que eu sou com a minha atual.

3. Em geral, acredito que outra seguradora seria menos onerosa do que a minha atual.

4. Eu acho que uma nova seguradora me ofereceria uma variedade mais completa de serviços.

Construto Lealdade - Referência: Picón et al. (2014)

\begin{tabular}{l}
\hline Perguntas Originais \\
\hline $\begin{array}{l}\text { 1. I really like doing business with } \\
\text { this company. }\end{array}$
\end{tabular}

2. To me, this company is clearly the best one with which to do business.

3. I believe this is a good company.

4. I try to use this company every time I need insurance services.

5. I consider this company to be my primary insurance company.

6. I consider this company to be my first choice when I need insurance services.

7. I intend to continue doing business with this company over the next few years. 0.63

8. As long as the present service continues, I doubt that I would switch insurance companies.
Perguntas Adaptadas para o Questionário

1. Eu realmente gosto de fazer negócios com minha seguradora

2. Para mim, a minha seguradora é claramente a melhor para se fazer negócios

3. Eu acredito que é uma boa seguradora

4. Eu tento usar esta seguradora toda vez que preciso de alguma apólice de seguro.

5. Eu considero esta companhia como a minha principal seguradora.

6. Eu considero esta companhia como a minha primeira escolha quando preciso de serviços de seguros.

7. Pretendo continuar fazendo negócios com esta seguradora nos próximos anos

8. Enquanto o serviço atual continuar, eu duvido que eu mudaria de seguradora.

\section{Construto Confiança - Referência: Aurier e N'Goala (2010)}

\begin{tabular}{|l|l|}
\hline Perguntas Originais & Perguntas Adaptadas para o Questionáro \\
\hline 1. My bank has high integrity. & 1. Minha Seguradora é altamente íntegra \\
\hline $\begin{array}{l}\text { 2. My bank can be counted on to } \\
\text { do what is right. }\end{array}$ & $\begin{array}{l}\text { 2. Posso contar que minha seguradora faz } \\
\text { o que é correto. }\end{array}$ \\
\hline 3. My bank cares about me. & 3. Minha seguradora se importa comigo. \\
\hline $\begin{array}{l}\text { 4. If problems arise, my bank is } \\
\text { honest about the problems. }\end{array}$ & $\begin{array}{l}\text { 4. Se algum problema surgir, minha } \\
\text { seguradora é honesta. }\end{array}$ \\
\hline
\end{tabular}




\subsection{2}

\section{Procedimentos de Tradução e Adaptação das Escalas Utilizadas}

Originalmente, as escalas utilizadas neste estudo foram desenvolvidas na língua inglesa, sendo necessária a tradução e adaptação de cada escala para o português permitindo assim a aplicação da pesquisa para respondentes brasileiros.

Sperber (2004) sugere que a adaptação de escalas para outras línguas deve passar por algumas etapas. Inicialmente, o questionário proposto foi traduzido por um profissional fluente em inglês independentemente e posteriormente revisado por um segundo. As traduções de cada escala foram então revisadas e comparadas por especialistas no tema (professores doutores pesquisadores de comportamento do consumidor) com fluência na língua inglesa para a obtenção da versão para português do instrumento de pesquisa.

\subsection{3}

\section{Pré-teste do Instrumento de Pesquisa}

Para a validação da tradução e da adequação do questionário, foi realizado um pré-teste com uma pequena amostra do público de interesse. Foi solicitado a 15 indivíduos que sinalizassem as dúvidas na compreensão do questionário ou que indicassem sugestões.

Nesta etapa, foi solicitado aos respondentes que anotassem ou apontassem qualquer tipo de dúvida ou dificuldade que porventura tivessem sobre a interpretação ou compreensão de qualquer um dos itens do instrumento de pesquisa. Foram incentivadas também sugestões, por parte dos respondentes, para melhorias na apresentação do questionário e nas instruções de preenchimento.

Os resultados obtidos com esse pré-teste inicial serviram para refinar o questionário e elaborar uma nova versão on-line. Essa versão ainda passou por um pré-teste final com 10 respondentes da população de interesse, onde foi verificado se algum último ajuste era necessário. Com os resultados deste último pré-teste, foi elaborado o instrumento de pesquisa final, apresentado no Apêndice $A$. 


\section{3 \\ População e Amostra}

\subsection{1}

\section{População}

A população de interesse é formada por adultos brasileiros que possuem ou já possuíram seguro de automóvel contratado nos últimos 24 meses.

\subsection{2 \\ Amostra}

Foi realizada uma amostragem não probabilística por conveniência, uma vez que não é possível conhecer nem conseguir acesso a todos os adultos que utilizam carros com seguro de automóvel contratado no Brasil, o que, de acordo com Parasuraman et al (2006), seria necessário para uma seleção aleatória correta.

Em amostras não probabilísticas a chance de seleção de um elemento da população é desconhecida, como destaca Hair et al. (2009). Em amostras por conveniência, a seleção dos elementos da amostra é feita por respondentes capazes de fornecer as informações requeridas e que estejam mais acessíveis e disponíveis para participar da pesquisa.

A amostra estudada foi composta por brasileiros predominantemente residentes do Rio de Janeiro, que utilizam carro com seguro de automóvel contratado durante o prazo máximo de dois anos anteriores ao momento da pesquisa.

Foi obtida uma amostra com 270 respondentes, dos quais 40 foram eliminados por apresentarem dados ausentes e outros 10 foram eliminados por informarem que não possuíam carro com seguro. Desta forma, a amostra final foi composta por 230 questionários válidos.

\section{4}

\section{Coleta de Dados}

\subsection{1}

\section{O Instrumento de Coleta de Dados}

Como indicado anteriormente, o instrumento de pesquisa foi um questionário estruturado (Apêndice A), composto por 38 itens, sendo que 7 itens mensuravam a satisfação do cliente, 15 itens mensuravam o custo de mudança, 4 itens abordavam a atratividade das alternativas, 8 itens analisaram a lealdade 
e finalmente a confiança foi abordada por 4 itens. Além dessas dimensões, o questionário também apresentava itens para avaliar o perfil dos respondentes com relação às suas experiências e percepções sobre o seu seguro de automóvel, proporcionando uma melhor compreensão da amostra envolvida na pesquisa.

O questionário foi estruturado iniciando com perguntas sobre características do perfil do respondente, seguidas por perguntas que avaliavam as experiências e percepções dos clientes de seguros de automóvel. Finalmente, foram apresentados os itens que medem os construtos propostos no modelo.

\subsection{2}

\section{A Coleta de Dados}

Nesta pesquisa foi escolhido o método survey para coleta de dados primários necessários no estudo proposto. O survey é uma opção adequada quando o objetivo é a coleta de dados com fins de investigação causal e generalização de resultados (COOPER e SCHINDLER, 2003). Este método possibilita a obtenção de uma grande quantidade de informações por respondente de uma única vez. A pesquisa de survey fornece um conjunto de dados que pode ser analisado, logo após a coleta, confirmando ou não uma determinada teoria (BABBIE, 2001).

Para isto foi elaborado o instrumento de pesquisa (Apêndice A) na plataforma do site Qualtrics.com. Posteriormente, o link de acesso ao questionário on-line foi distribuído via aplicativo de mensagem para smartphones (Whatsapp) e por meio de mensagens em redes sociais (Facebook e Linkedin) para cerca de 500 indivíduos da rede do pesquisador. Como o perfil do respondente era razoavelmente específico, não foi solicitado repassar o link da pesquisa para evitar respondentes fora do público alvo. Apenas 3 indivíduos, que receberam uma instrução prévia sobre o perfil do respondente desejado, ajudaram na distribuição do questionário.

O processo de coleta de dados foi realizado ao longo do mês de fevereiro de 2017 e a participação dos respondentes foi voluntária e confidencial. Era esperado que os respondentes fossem adultos maiores de 18 anos e tivessem algum conhecimento e/ou experiência de uso com seguro de automóvel, por isso foram considerados apenas respondentes que utilizassem carro com seguro de automóvel contratado no período de até dois anos ao momento da pesquisa, resultando em uma amostra final com 230 respostas válidas. O questionário era auto administrado e os participantes foram voluntários interessados no tema. 


\section{5}

\section{Análise de Dados}

Após a aplicação de todos os questionários, os dados foram reunidos para processamento estatístico em uma base de dados do SPSS. Foi realizada também uma limpeza dos dados para identificar e excluir informações ausentes e dados errôneos que não deveriam ser considerados na análise, o que resultou na eliminação 50 registros. Dessa forma, a amostra válida totalizou 230 respostas. Nesse momento, também foi feita uma análise das variáveis demográficas presentes no questionário para caracterizar a amostra pesquisada.

\subsection{1}

\section{Validade e Confiabilidade}

Nesta etapa, foi efetuada uma análise fatorial confirmatória (CFA) para avaliar a confiabilidade e a validade dos dados coletados, a fim de desenvolver o modelo de mensuração e também analisar as propriedades dos construtos utilizados no instrumento de pesquisa. Conforme Hair et al. (2009) e Churchill (1979), a validade de um construto demonstra quanto uma escala de fato reflete um construto latente que ela se propõe a medir. A confiabilidade diz respeito ao quanto um conjunto de variáveis é consistente em relação ao que se pretende medir.

A confiabilidade dos construtos foi avaliada através do Alfa de Cronbach (Nunnally, 1978) e da confiabilidade composta (Composite Reliability - CR). Os valores do Alfa de Cronbach e da confiabilidade composta são considerados adequados quando superiores a 0,8 , sendo considerado aceitáveis com valores acima 0,7 .

A validade dos construtos foi avaliada por meio do exame das cargas fatoriais dentro de cada construto e da correlação entre construtos resultantes da CFA realizada. Para avaliar a validade convergente, o grau com o qual os diferentes indicadores de cada escala se referem ao mesmo construto (Hair et al., 2009), foi utilizada a variância extraída média (Average Variance Extracted AVE). Uma AVE superior a 0,5 é sugerida por Fornell e Larcker (1981) e Hair et al. (2009) como indicador adequado de validade convergente.

A validade discriminante foi avaliada através da análise das cargas fatoriais de cada item devendo ser maiores em relação aos construtos que supostamente medem do que em relação a outros construtos presentes no modelo (HAIR et al, 2009). Os dados foram interpretados de acordo com a sugestão de HAIR et al (2009), que afirma que as cargas fatoriais maiores do 
que 0,3 podem ser consideradas significativas, maiores do que 0,4 podem ser consideradas importantes e maiores do que 0,5 podem ser consideradas muito significativas. A validade discriminante também foi verificada pelo método sugerido por Hair et al. (2009), sendo realizada a comparação da AVE de cada par de construtos com o quadrado da estimativa de correlação entre estes dois construtos. O valor da AVE deve ser sempre maior do que a estimativa de correlação ao quadrado.

\section{5 .2}

\section{Análises Estatísticas}

Com o uso do software AMOS, as hipóteses do estudo foram testadas por meio de modelagem de equações estruturais (SEM). A escolha desse método é apropriada para responder às questões apresentadas neste estudo e aos testes exigidos pelas hipóteses sugeridas, pois permite a estimação de relações simultâneas entre várias variáveis independentes e dependentes (BAGOZZI; PHILLIP, 1982). A utilização de SEM possibilita a avaliação conjunta dos efeitos dos construtos envolvidos em um modelo proposto, evitando distorções que poderiam ocorrer nas dependências observadas entre as variáveis, caso elas fossem estudadas separadamente (HAIR et al., 2009).

Para avaliação e ajuste dos modelos CFA e SEM foram utilizados índices aplicados em outros estudos similares (PICÓN et al., 2014). Os índices utilizados foram o Tucker-Lewis index (TLI ou NNFI), o comparative fit index (CFI), o root mean squared approximation error (RMSEA) e a estatística qui-quadrada do modelo (juntamente com os graus de liberdade associados). Todos esses índices (com exceção da estatística qui-quadrada) são de fácil interpretação por estarem em uma escala contínua de 0 a 1 e são relativamente independentes de efeitos ligados ao tamanho da amostra.

\section{6}

\section{Limitações do Método}

\subsection{1}

\section{Limitações relacionadas ao critério de amostragem}

A delimitação do universo amostral do estudo e a amostra por conveniência realizada prejudicam a representatividade da amostra, mesmo com a população de interesse tendo sido definida como "adultos que utilizem carro com seguro de automóvel contratado". De qualquer forma, conforme Ferreira (2010) a representatividade da amostra não é uma questão crucial, visto que o 
objetivo da pesquisa é testar a estrutura de relações proposta entre variáveis e não a validade externa dos resultados.

A delimitação amostral consiste de adultos brasileiros de qualquer região do país que possuem ou já possuíram seguro de automóvel contratado nos últimos 2 anos anteriores ao momento da pesquisa. Em função da seleção por conveniência, a amostra apresentou um viés de lugar, com a grande maioria dos respondentes residentes da região metropolitana do Rio de Janeiro, e uma concentração de renda familiar estimada alta comparada com a média da população brasileira. Esses vieses devem ser considerados no resultado da pesquisa.

\subsection{2}

\section{Limitações decorrentes da coleta de dados}

A delimitação do universo amostral do estudo e a amostra por conveniência, realizada em grande maioria com respondentes residentes da cidade do Rio de Janeiro, prejudica a representatividade da amostra, mesmo com a população de interesse tendo sido definida como "adultos que utilizem carros com seguro de automóvel contratado". Pode existir um viés de locus devido ao fato de uma grande parte dos respondentes serem da mesma cidade.

Outra limitação da coleta de dados nesta pesquisa é decorrente da experiência de uso por parte dos clientes de seguros de automóvel. Alguns respondentes afirmaram que não participam da negociação e contratação do seguro de automóvel, assim como outros declararam nunca ter utilizado o seguro através de solicitação de pagamento de indenização de sinistro ou por nunca ter utilizado algum serviço da assistência 24 horas como reboque, mecânico ou chaveiro, o que pode ocasionar algumas distorções nas respostas. Por isso, o estudo assume a premissa de que as pessoas responderam o mais próximo da verdade sobre sua experiência e conhecimento com o seu seguro de automóvel contratado. 


\section{4 \\ Modelagem e análise de dados}

Nesta seção, são avaliadas as propriedades estatísticas e as métricas coletadas da amostra. Do mesmo modo são avaliados os modelos de mensuração e estruturais propostos e também os resultados dos testes das hipóteses de pesquisa.

\section{1}

\section{Caracterização da Amostra}

De acordo com algumas estatísticas descritivas, o Quadro 4.1 apresenta as características da amostra final, composta por 230 respostas válidas. A amostra apresentou uma concentração de respondentes do sexo masculino (80\%), com apenas $20 \%$ dos respondentes sendo do sexo feminino. Com relação à faixa etária dos respondentes, $48,70 \%$ estão na faixa entre 30 a 50 anos, seguidos de $29,57 \%$ que afirmaram estar na faixa entre 18 a 30 anos e por fim 21,74\% apontaram ter mais de 50 anos. Com relação à renda mínima familiar, a maior parte com $46 \%$ dos participantes estima uma renda acima de 10 mil reais, 34\% estimaram uma renda entre 5 a 10 mil e 20\% estimaram renda na faixa entre mil a 5 mil reais. Nenhum respondente afirmou ter uma renda familiar abaixo de mil reais.

Do total de 230 participantes, 153 participam da negociação e contratação do seguro de automóvel representando $66,5 \%$ do total da amostra, enquanto 77 dos respondentes (34,5\% do total) apenas utilizam o veículo e não participam do processo de contratação do seguro de automóvel.

Outra característica verificada foi o tempo que o indivíduo possui seguro de automóvel contratado. Com relação a este tempo de experiência com seguros, a amostra apresentou uma concentração de participantes com mais de 5 anos de seguros de automóvel contratado. As faixas foram distribuídas da seguinte maneira: 35\% dos respondentes possuem seguro a mais de 10 anos, $21 \%$ estão na faixa entre 1 e 2 anos, 22\% se encontram na faixa entre 3 a 5 e por fim na faixa entre 5 e 10 anos estão $22 \%$ do total.

Dentre todos os participantes, 54\% dos respondentes afirmaram que já tiveram indenização paga pela seguradora decorrente de algum sinistro e menos 
de $2 \%$ afirmaram que já tiveram algum pedido de indenização recusado pela seguradora.

Além de pagamentos de indenizações, outra forma de utilizar o seguro é através do acionamento de algum serviço da assistência 24 horas. Dentre os respondentes $71 \%$ informaram que já utilizaram algum desses serviços como reboque, mecânico ou chaveiro.

$\mathrm{Na}$ pesquisa, $87 \%$ dos respondentes informaram que não imaginam a possibilidade de deixar o seu carro sem a contratação do seguro de automóvel. Ao mesmo tempo, 80\% afirmaram que o seguro de automóvel custa muito caro. Dentre os fatores mais importantes na contratação do seguro listado, a credibilidade apareceu em primeiro lugar com 34\%, seguido do preço e forma de pagamento com 26\%. Em terceiro lugar estavam os tipos de coberturas e serviços disponíveis com 26\%, em quarto apareceram a qualidade no atendimento e rapidez com $9 \%$ e, por fim, as indicações do corretor ou de terceiros com $5 \%$.

\section{Quadro 4.1: Características da Amostra}

\begin{tabular}{|c|c|c|}
\hline \multicolumn{3}{|c|}{$\begin{array}{l}\text { Você participa da negociação e contratação do seguro de automóvel juntamente } \\
\text { com o corretor? }\end{array}$} \\
\hline Resposta & $(\mathrm{N})$ & $\%$ \\
\hline Sim & 153 & $66,52 \%$ \\
\hline Não & 77 & $34,48 \%$ \\
\hline Total & 230 & $100,00 \%$ \\
\hline \multicolumn{3}{|c|}{ Por quantos anos possui seguro de automóvel contratado? } \\
\hline Resposta & $(\mathrm{N})$ & $\%$ \\
\hline 1 a 2 anos & 51 & $22,17 \%$ \\
\hline 3 a 5 anos & 50 & $21,74 \%$ \\
\hline 5 a 10 anos & 49 & $21,30 \%$ \\
\hline Mais de 10 anos & 80 & $34,78 \%$ \\
\hline Total & 230 & $100,00 \%$ \\
\hline \multicolumn{3}{|c|}{$\begin{array}{l}\text { Já teve alguma indenização paga pela seguradora decorrente de algum sinistro } \\
\text { (prejuízo)? }\end{array}$} \\
\hline Resposta & $(\mathrm{N})$ & $\%$ \\
\hline Sim & 105 & $45,65 \%$ \\
\hline Não & 125 & $54,35 \%$ \\
\hline Total & 230 & $100,00 \%$ \\
\hline \multicolumn{3}{|c|}{ Alguma indenização recusada? } \\
\hline Resposta & $(\mathrm{N})$ & $\%$ \\
\hline Sim & 4 & $1,74 \%$ \\
\hline Não & 226 & $98,26 \%$ \\
\hline Total & 230 & $100,00 \%$ \\
\hline
\end{tabular}




\begin{tabular}{|c|c|c|}
\hline \multicolumn{3}{|c|}{$\begin{array}{l}\text { Já utilizou algum serviço da assistência } 24 \text { horas como reboque, mecânico ou } \\
\text { chaveiro? }\end{array}$} \\
\hline Resposta & $(\mathrm{N})$ & $\%$ \\
\hline Sim & 163 & $70,87 \%$ \\
\hline Não & 67 & $29,13 \%$ \\
\hline Total & 230 & $100,00 \%$ \\
\hline \multicolumn{3}{|c|}{ Você imagina a possibilidade de deixar seu carro sem a contratação de seguro? } \\
\hline Resposta & $(\mathrm{N})$ & $\%$ \\
\hline Sim & 29 & $12,61 \%$ \\
\hline Não & 201 & $87,39 \%$ \\
\hline Total & 230 & $100,00 \%$ \\
\hline \multicolumn{3}{|c|}{ Na sua opinião, o seguro de automóvel custa muito caro? } \\
\hline Resposta & $(\mathrm{N})$ & $\%$ \\
\hline Sim & 183 & $79,57 \%$ \\
\hline Não & 47 & $20,43 \%$ \\
\hline Total & 230 & $100,00 \%$ \\
\hline \multicolumn{3}{|c|}{ Determine o fator mais importante na contratação de um seguro de automóvel? } \\
\hline Resposta & $(\mathrm{N})$ & $\%$ \\
\hline $\begin{array}{l}\text { Credibilidade e reputação da } \\
\text { seguradora }\end{array}$ & 79 & $34,35 \%$ \\
\hline Indicação do corretor ou de terceiros & 12 & $5,22 \%$ \\
\hline Preço e forma de pagamento & 60 & $26,09 \%$ \\
\hline Qualidade no atendimento e rapidez & 20 & $8,70 \%$ \\
\hline $\begin{array}{l}\text { Tipos de coberturas e serviços } \\
\text { disponíveis }\end{array}$ & 59 & $25,65 \%$ \\
\hline Total & 230 & $100,00 \%$ \\
\hline \multicolumn{3}{|l|}{ Idade: } \\
\hline Resposta & $(\mathrm{N})$ & $\%$ \\
\hline 18 a 30 anos & 68 & $29,57 \%$ \\
\hline 30 a 50 anos & 112 & $48,70 \%$ \\
\hline Mais de 50 anos & 50 & $21,74 \%$ \\
\hline Total & 230 & $100,00 \%$ \\
\hline \multicolumn{3}{|l|}{ Sexo: } \\
\hline Resposta & $(\mathrm{N})$ & $\%$ \\
\hline Masculino & 183 & $79,57 \%$ \\
\hline Feminino & 47 & $20,43 \%$ \\
\hline Total & 230 & $100,00 \%$ \\
\hline \multicolumn{3}{|c|}{ Você estima que sua renda familiar média esteja em que faixa de valores: } \\
\hline Resposta & $(\mathrm{N})$ & $\%$ \\
\hline Abaixo de 1.000 reais & 0 & $0,00 \%$ \\
\hline 1.000 a 5.000 reais & 45 & $19,57 \%$ \\
\hline 5.000 a 10.000 reais & 78 & $33,91 \%$ \\
\hline Acima de 10.000 reais & 107 & $46,52 \%$ \\
\hline Total & 230 & $100,00 \%$ \\
\hline
\end{tabular}




\begin{tabular}{|l|r|r|}
\hline \multicolumn{1}{|c|}{ Qual é a sua seguradora de automóvel? } \\
\hline SulAmérica & $(\mathrm{N})$ & \multicolumn{1}{c|}{$\%$} \\
\hline Porto Seguro & 62 & $29,96 \%$ \\
\hline Azul & 44 & $19,13 \%$ \\
\hline Tokio Marine & 32 & $13,91 \%$ \\
\hline Outros & 19 & $8,26 \%$ \\
\hline Itaú & 19 & $8,26 \%$ \\
\hline BB Mapfre & 13 & $5,65 \%$ \\
\hline Bradesco & 12 & $5,22 \%$ \\
\hline Generali & 11 & $4,78 \%$ \\
\hline HDI & 6 & $2,61 \%$ \\
\hline Allianz & 6 & $2,61 \%$ \\
\hline Liberty & 4 & $1,74 \%$ \\
\hline Total & 2 & $0,87 \%$ \\
\hline
\end{tabular}

Fonte: Própria

\section{2}

\section{Análises e Resultados}

\subsection{1}

\section{Avaliação do Modelo de Mensuração}

No presente estudo, foi realizada uma análise fatorial confirmatória (CFA) para analisar a validade, a unidimensionalidade e a confiabilidade das escalas utilizadas no modelo de mensuração. Esta análise possibilitou avaliar o quanto cada item medido no modelo de mensuração se relaciona com cada construto em particular.

Para avaliar o ajuste do modelo de mensuração proposto, foram utilizados diversos índices de ajustes, sendo eles índices incrementais e índices absolutos, pois não existe ainda um consenso na literatura sobre qual índice é o mais adequado para verificar o ajuste de modelos desta natureza (HU, BENTLER, 1999; SCHREIBER et al., 2006).

Inicialmente, com o modelo utilizando todos os 38 indicadores medidos, os índices de ajuste encontrados ficaram abaixo dos valores recomendados pela literatura. Diversos itens que poderiam estar contribuindo para que o ajuste do modelo ficasse aquém do sugerido foram identificados por uma análise da matriz de covariância dos resíduos padronizados da CFA.

A partir do resultado obtido, foi possível refinar e ajustar o modelo levando à eliminação de alguns itens que não estavam se adequando à estrutura dos construtos. Assim, foram eliminados 11 itens no total, sendo 2 dos 7 itens na escala utilizada em Satisfação, 5 de 15 itens excluídos na escala de custo de 
troca, 1 dos 4 itens da escala de atratividade das alternativas, 2 dos 8 itens da escala de lealdade e por fim 1 dos 4 da escala de confiança.

Assim, o modelo de mensuração final, com 27 indicadores, apresentou índices de ajuste razoáveis $(\mathrm{SRMR}=0,0654$; RMSEA=0,087 com C.I. de 0,080 até 0,094; $\mathrm{CFI}=0,868 ; \mathrm{IFI}=0,869 ; \mathrm{TLI}=0,852 ; x^{2}=858,052$, d.f. $=314, p<0,001$, $x^{2} /$ d.f. $\left.=2,733\right)$, o que representou uma melhoria significativa em relação ao modelo inicial. Em conjunto, estes índices apontam que os dados se ajustam de maneira satisfatória ao modelo proposto (HU, BENTLER, 1999; SCHREIBER et al., 2006).

\subsection{2}

\section{Validade e Confiabilidade dos Construtos}

Segundo Hair et al., (2009), os quatro componentes que compõem a validade de um construto são: a validade de face, a validade nomológica, a validade convergente e a validade discriminantes

A validade de face é a consistência do conteúdo de cada item em relação ao construto por ele medido. Alguns critérios foram adotados durante o desenvolvimento do instrumento de pesquisa para garantir esta validade. $\mathrm{O}$ presente estudo optou por utilizar escalas já testadas anteriormente na literatura e realizou uma tradução criteriosa dessas escalas do inglês para o português. Nesta fase, também foi feita uma avaliação de cada item utilizado e por fim foram conduzidos pré-testes com pequenas amostras da população de interesse.

Já a validade nomológica examina as correlações entre os construtos da teoria de mensuração aplicada, analisando se as mesmas fazem sentido. A avaliação desta validade pode ser feita com o uso de uma matriz de correlação entre construtos, onde seja possível verificar se os construtos se relacionam entre si conforme previsto pela teoria.

Conforme a revisão de literatura realizada, se espera uma relação positiva entre os antecedentes da satisfação, custo de troca, confiança e da lealdade. $\mathrm{Na}$ relação entre satisfação e atratividade das alternativas se espera uma relação negativa. Também se espera uma relação negativa na relação dos construtos atratividade das alternativas e da lealdade. O quadro 4.2 apresenta a matriz de correlação dos construtos estudados. 
Quadro 4.2: Matriz de Correlação entre Construtos

\begin{tabular}{|c|c|c|c|c|c|}
\hline & SAT & CUT & ATA & COF & LEA \\
\hline SAT & 1 & $-0,054$ & $-0,320$ & 0,57 & 0,571 \\
\hline CUT & $-0,054$ & 1 & 0,243 & 0,051 & 0,225 \\
\hline ATA & $-0,320$ & 0,243 & 1 & $-0,034$ & $-0,214$ \\
\hline COF & 0,570 & 0,051 & $-0,034$ & 1 & 0,657 \\
\hline LEA & 0,571 & 0,225 & $-0,214$ & 0,657 & 1 \\
\hline
\end{tabular}

Fonte: Própria

* = correlação não significativa

Onde:

- $\quad$ SAT = Satisfação

- $\quad$ CUT = Custo de Troca

- $\quad \mathrm{ATA}=$ Atratividade das Alternativas

- $\mathrm{COF}=$ Confiança

- $\quad$ LEA = Lealdade

Pode-se concluir que os construtos utilizados apresentam a validade nomológica, uma vez que todas as correlações são consistentes com a teoria estudada.

Conforme Fornell e Larcker (1981), a avaliação da consistência interna e da confiabilidade das escalas foi feita a partir da confiabilidade composta que representa a consistência interna de indicadores que medem um mesmo fator. Os autores recomendam valores acima de 0,7 com relação à confiabilidade composta. A tabela 4.1, com todas as escalas apresentando números acima de 0,7 , indica que todas as escalas utilizadas possuem os níveis mínimos de confiabilidade considerados adequados pela literatura.

Foi calculada a variância extraída média para cada construto (average variance extracted - AVE) para avaliar a validade convergente. A validade convergente é considerada adequada quando estimativas de AVE são maiores do que 0,50 (Fornell e Larcker, 1981). A tabela 4.1 apresenta os resultados obtidos no presente estudo indicando a confirmação da validade convergente das escalas utilizadas, pois todos os valores AVE calculados estão entre 0,56 e 0,72 (acima do nível recomendado de 0,5 ). 
Tabela 4.1: Confiabilidade Composta e Variância Extraída Média (AVE)

\begin{tabular}{|l|c|c|}
\hline \multicolumn{1}{|c|}{ Escala } & $\begin{array}{c}\text { Confiabilidade } \\
\text { Composta }\end{array}$ & AVE \\
\hline Satisfação & 0,91 & 0,68 \\
Custo de Troca & 0,93 & 0,56 \\
Atratividade das & 0,87 & 0,70 \\
alternativas & 0,89 & 0,72 \\
Confiança & 0,92 & 0,67 \\
Lealdade & & \\
\hline
\end{tabular}

Fonte: Própria

Com relação à validade discriminante, segundo Ferreira (2010), pode-se dizer que ela ocorre quando todos os construtos apresentam variâncias extraídas maiores do que as respectivas variâncias compartilhadas. Ou seja, os itens se relacionam mais fortemente com os construtos aos quais devem se referir do que com outros construtos presentes no modelo. Fornell e Larcker (1981) afirmam que para se avaliar esta validade é preciso comparar a variância extraída média (AVE) de cada construto com a variância compartilhada (o quadrado do coeficiente de correlação) entre todos os pares de construtos.

A matriz para a análise da validade discriminante é apresentada pelo quadro 4.3, onde podemos identificar a diagonal principal contendo a AVE para cada construto e os demais itens apresentando o quadrado dos coeficientes de correlação entre cada par de construtos. É possível identificar que as variâncias compartilhadas são inferiores à AVE a partir da análise da matriz, confirmando assim que a validade discriminante está adequada.

Quadro 4.3: Matriz de Validade Discriminante

\begin{tabular}{|c|c|c|c|c|c|}
\cline { 2 - 6 } \multicolumn{1}{c|}{} & SAT & CUT & ATA & COF & LEA \\
\hline SAT & 0,68 & $-0,054$ & $-0,320$ & 0,570 & 0,571 \\
\hline CUT & 0,003 & 0,56 & 0,243 & 0,510 & 0,225 \\
\hline ATA & 0,102 & 0,059 & 0,70 & $-0,034$ & $-0,214$ \\
\hline COF & 0,325 & 0,260 & 0,001 & 0,72 & 0,657 \\
\hline LEA & 0,326 & 0,050 & 0,045 & 0,431 & 0,67 \\
\hline
\end{tabular}

Fonte: Própria

Após a análise conjunta dos resultados obtidos para análise fatorial confirmatória podemos observar que o modelo de mensuração proposto atende 
aos requisitos esperados de confiabilidade, unidimensionalidade, validade de face, validade nomológica, validade convergente e validade discriminante. Desta forma, é então viável a investigação das relações entre os construtos latentes por meio de um modelo estrutural.

\section{3}

\section{Análise do Modelo Estrutural}

O modelo conceitual proposto foi estimado e as hipóteses de pesquisa testadas via modelagem via equações estruturais (SEM). Foi utilizado o software AMOS 20. Conforme Byrne (2010), a significância dos coeficientes estimados para as relações presentes no modelo aponta se cada hipótese é verificada ou não. Por fim, é feita uma modelagem da estrutura proposta e através dos índices de ajuste relevantes se verifica se está adequada ou não.

\subsection{1}

\section{Ajuste no Modelo Proposto}

Diversos índices de ajuste foram utilizados para examinar o modelo proposto, conforme figura 4.1 (GARVER, MENTZER, 1999; HAIR et al., 2009).

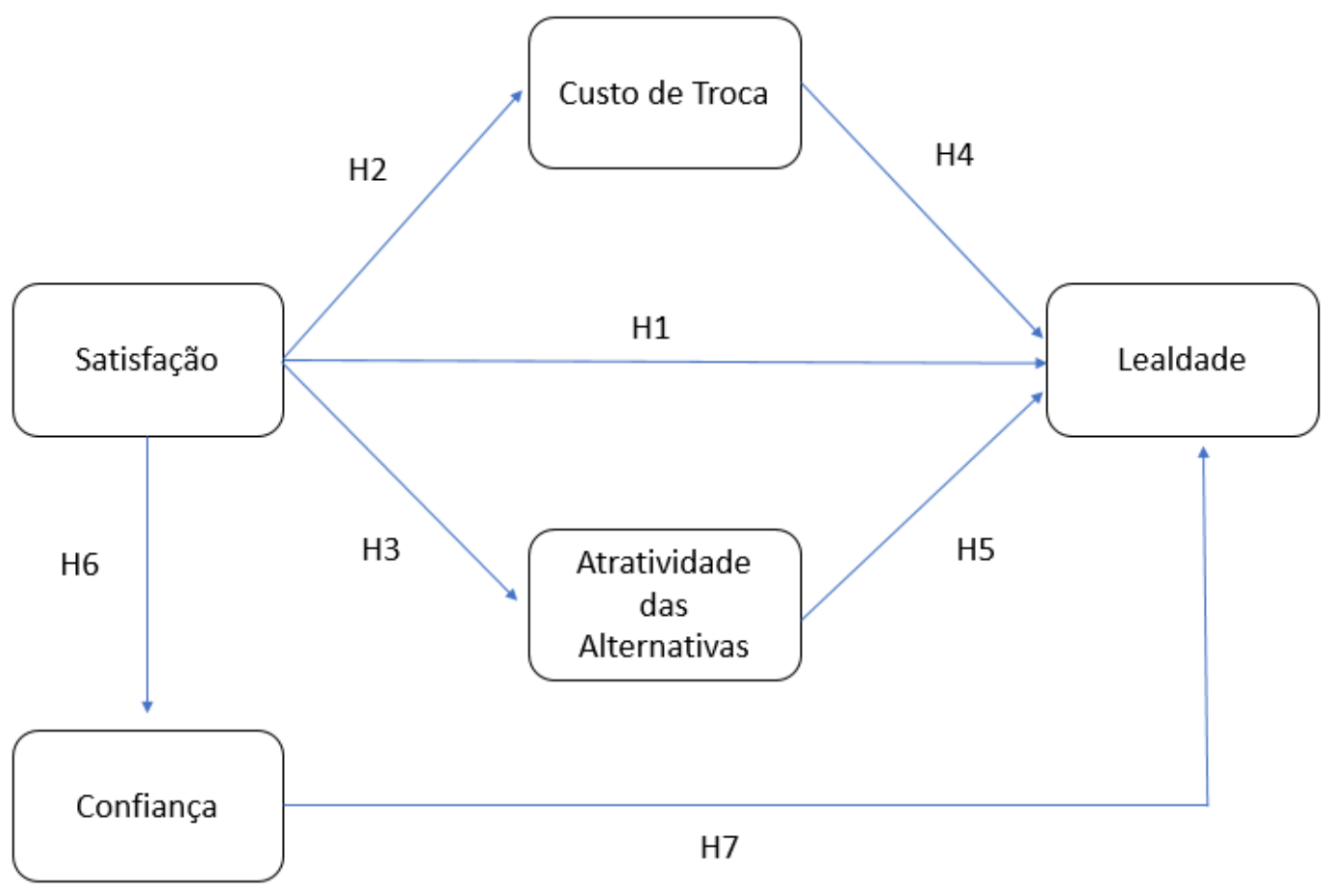

Figura 4.1: Modelo Proposto Fonte: Própria

Estatisticamente, o modelo obteve uma estatística qui-quadrado significativa $(x 2=675,578$, d.f. $=284, p<0,001)$. Porém, é preciso cuidado na 
interpretação desde índice, como sugerem alguns autores, uma vez que ele é sensível à violações da premissa de normalidade e também sensível ao tamanho da amostra (BENTLER, 1990; HOOPER et al., 2008).

Todos os demais índices indicam um ajuste razoável do modelo. A razão X2/d.f. foi de 2,73, inferior ao valor de 3,0 sugerido por Byrne (2010). O SRMR (standardized root mean square residual) foi de 0,081, enquanto o RMSEA (root mean square error of approximation) foi de 0,088 (C. I. de 0,081 até 0,095), ambos próximos de 0,08 , conforme recomendado pela literatura (HU, BENTLER, 1999). Por sua vez, os índices de ajuste incrementais (BENTLER, BONNET, 1980), foram próximos ao sugerido de 0,90, com um CFI (comparative fit index) de 0,87, um TLI (Tucker-Lewis index) de 0,85 e um IFI (incremental fit index) de 0,87 . Estes resultados encontram-se resumidos na tabela 4.2. Considerando-se os índices apresentados, pode-se concluir que o ajuste do modelo proposto é satisfatório.

Tabela 4.2: Índices de Ajuste do Modelo

\begin{tabular}{|c|c|c|}
\hline Índice de Ajuste & Modelo Proposto & Valor sugerido pela literatura \\
\hline X$^{2} /$ d.f. & 2,76 & $\leq 3$ \\
CFI & 0,87 & $\geq 0,90$ \\
TLI & 0,85 & $\geq 0,90$ \\
IFI & 0,87 & $\geq 0,90$ \\
RMSEA & 0,088 & $\leq 0,08$ \\
SRMR & 0,081 & $\leq 0,08$ \\
\hline
\end{tabular}

Fonte: Própria

\subsection{2}

\section{Teste das Hipóteses de Pesquisa}

Através da análise da magnitude, direção e significância dos coeficientes padronizados estimados pelo modelo estrutural (BYRNE, 2010; KULVIWAT et al., 2007) foi feita a verificação das hipóteses de pesquisa. Uma relação foi considerada significativa se o p-value para o teste $t$ associado ao coeficiente estimado foi inferior a um nível de significância de 0,05 (BYRNE, 2010; HAIR et al., 2009). Os coeficientes estimados para o modelo proposto, assim como as hipóteses de pesquisa e significâncias associadas, podem ser observados na tabela 4.3 e encontram-se ilustrados na figura 4.2 . 
Tabela 4.3: Coeficientes Padronizados Estimados, Hipóteses e Significâncias para o Modelo Proposto.

\begin{tabular}{|l|c|c|c|}
\hline Relação Proposta & $\begin{array}{c}\text { Coeficiente } \\
\text { Padronizado }\end{array}$ & p-valor & $\begin{array}{c}\text { Hipótese } \\
\text { Verificada }\end{array}$ \\
\hline H1: Satisfação > Lealdade & 0,247 & $<0,001$ & Sim \\
H2: Satisfação > Custo de Troca & $-0,054$ & 0,447 & Não \\
H3: Satisfação > Atratividade & $-0,314$ & $<0,001$ & Sim \\
H4: Custo de Troca > Lealdade & 0,252 & $<0,001$ & Sim \\
H5: Atratividade > Lealdade & $-0,167$ & 0,007 & Sim \\
H6: Satisfação > Confiança & 0,566 & $<0,001$ & Sim \\
H7: Confiança > Lealdade & 0,490 & $<0,001$ & Sim \\
\hline
\end{tabular}

Fonte: Própria

Os resultados apresentados pela tabela 4.3 e na figura 4.2 permitem observar que foi obtido suporte confirmatório para seis das sete hipóteses de pesquisa propostas. Dessas seis, cinco são significativas a um nível de 0,001 enquanto uma (o efeito da atratividade das alternativas sobre a lealdade) é significativa a um nível de 0,05.

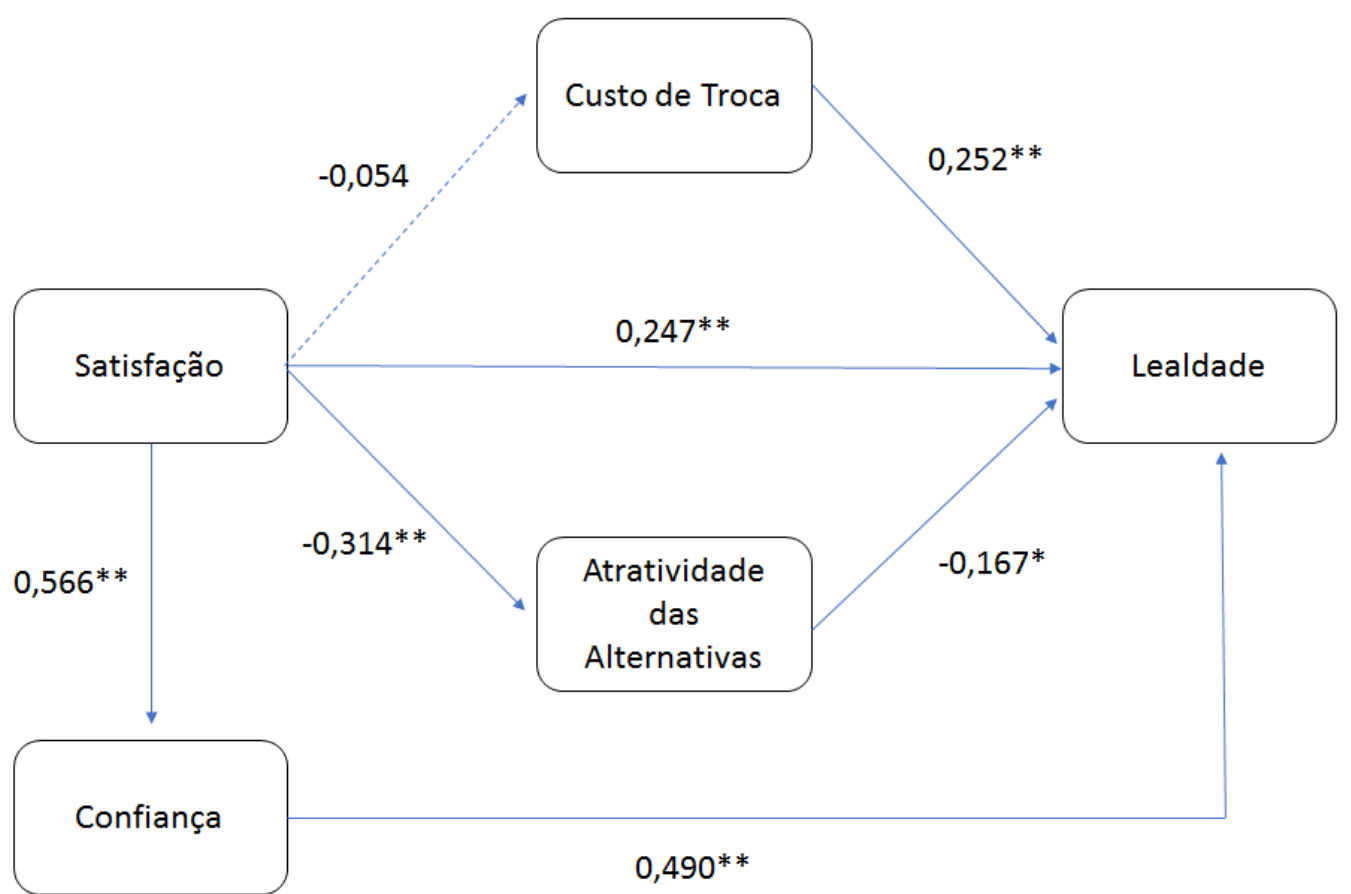

Figura 4.2: Modelo Proposto, Coeficientes Padronizados e Significâncias. (* indica p-valor $<0,05$; ** indica p-valor $<0,001$ ) Fonte: Própria 


\section{4 \\ Discussão dos Resultados}

\subsection{1 Satisfação}

A confirmação da relação entre a satisfação e a lealdade, hipótese $H 1$, está de acordo com os resultados obtidos por outros pesquisadores (OLIVER, 1999; PATTERSON e SMITH, 2003; TSAI, HUANG, JAW, e CHEN, 2006; VALVI, FRAGKOS, 2012). O resultado indica um efeito direto e razoavelmente significativo (coeficiente padronizado de 0,247 ) da satisfação sobre a lealdade do cliente no mercado de seguros. Este resultado reforça as conclusões do estudo de Picón et al. (2014), onde o autor sugere que as seguradoras devem focar na qualidade de serviço quando ofertam seus seguros. Segundo o mesmo autor, quanto maior o nível da satisfação, maior será a lealdade dos clientes. O segurado fica satisfeito quando a seguradora atende suas necessidades específicas, apresentando assim pouca inclinação para o rompimento da relação existente. Oliver (1999) sugere que a satisfação é um passo importante e necessário no processo da construção da lealdade. Algumas estratégias adequadas para aumentar a lealdade são: desenvolver uma política de fidelidade do cliente adequada, melhoria contínua na qualidade do serviço, práticas eficazes de recuperação de serviços, treinamento da equipe de vendas, etc. Essas ações estratégicas levam os consumidores a adotarem uma atitude positiva e uma vontade de manter o relacionamento no longo prazo, o que favorece a lealdade (CARUANA, 2002, GREMLER et al., 2001). Dentro no contexto do mercado de seguros, a satisfação é muito importante pelo tipo de serviço prestado. O seguro é um produto que o cliente compra, mas não deseja utilizar, pois um segurado não almeja ser furtado ou se envolver em um acidente de trânsito. Em alguns casos, pode-se passar anos sendo cliente sem nunca ter uma experiência relevante com a seguradora. Essa natureza exige que a hora da verdade no acionamento de um seguro seja precisa e eficiente. Uma reclamação de sinistro se caracteriza por ser um momento de tensão e estresse, onde o emocional do segurado já está comprometido e uma falha pode acarretar em uma péssima experiência, eventualmente causando uma grande insatisfação a ponto do cliente preferir mudar de seguradora.

A relação entre a satisfação e o custo de troca, representada pela hipótese $\mathrm{H} 2$, não foi confirmada. A pesquisa apontou uma relação não significativa ( $p$ valor de 0,447$)$ entre satisfação do cliente e custo de troca. O resultado não está de acordo com estudos anteriores (NGOBO, 2004; BARROSO e PICÓN, 2012; 
PICÓN et al., 2014) que afirmam que a satisfação do cliente tem um efeito positivo sobre os custos de troca. O que pode ser uma explicação para o resultado encontrado é o fato do mercado de seguros brasileiro apresentar muita concorrência, atualmente mais de 10 seguradoras atuam com seguro de automóvel. A maioria investe na qualidade do serviço ao mesmo tempo que buscam oferecer seguros com preços competitivos. Assim, a satisfação é uma exigência dos consumidores e não um diferencial, fazendo com que a satisfação não influencie diretamente no custo de mudança de seguradora. Outro fator a ser destacado é a rigorosa regulação da autarquia que supervisiona todo o mercado de seguros que de certa forma padroniza os serviços das grandes companhias de seguro de automóvel. Como os segurados se sentem amparados pela fiscalização do governo e pelo código de defesa do consumidor podem ter uma percepção menor de risco de ter uma experiência de consumo insatisfatória. Por fim, pode haver uma certa distância entre o segurado e a seguradora devido à relevância do papel do corretor que ainda é muito forte na mediação entre as partes. O corretor é um intermediário que é responsável por representar o cliente perante a seguradora, diminuindo uma percepção de perda no relacionamento em uma eventual troca de seguro.

A influência da satisfação na atratividade das alternativas, hipótese $H 3$, foi verificada. O resultado está coerente com os estudos anteriores (PATTERSON e SMITH, 2003; ANTÓN et al., 2007; PICÓN et al., 2014). A confirmação dessa hipótese sugere que quanto maior a satisfação de um cliente maior será a sua resistência a iniciativas de persuasão de concorrentes. O cliente satisfeito terá uma probabilidade maior de apresentar uma atratividade das alternativas com nível mais baixo (BANSAL et al., 2005). Os segurados mais satisfeitos percebem como menor o benefício da troca, tendo em vista que possuem maior probabilidade de avaliar seu seguro de automóvel como superior na análise custo-benefício perante a concorrência. Assim, a satisfação atua diretamente na percepção de que outros seguros existentes no mercado são menos atraentes do que o atual. Outro motivo da satisfação possuir relação direta e significativa com a atratividade das alternativas, é que indivíduos quando insatisfeitos com aspectos como qualidade de serviço ou preço tendem a procurar conhecer alternativas disponíveis, apresentando, portanto, maior inclinação para o rompimento do relacionamento. Em contrapartida, a satisfação inibe a inclinação de mudança diminuindo assim a atratividade das alternativas (Antón et al., 2007). 


\subsection{2 \\ Custo de Troca, Atratividade das Alternativas e Lealdade}

A relação entre custo de troca e lealdade dos clientes, hipótese H4, é significativa. Esse resultado está alinhado com as conclusões de estudos anteriores (MORGAN e HUNT,1994; NGOBO, 2004; BANSAL et al, 2005; PICÓN et al., 2014), que sugerem que há uma relação entre os dois construtos. A relação entre custo de troca e lealdade indica que quando os clientes entendem que o esforço para adquirir um seguro é grande, eles tendem a se manter leais. De acordo com a tipologia de custo de troca de Burnham et al. (2003), podemos destacar na pesquisa os resultados de custo de avaliação, aprendizagem e de inicialização já que $54 \%$ dos respondentes afirmaram que não dispõe de tempo para buscar informações completas para avaliar outras seguradoras e $60 \%$ dos respondentes consideram que é preciso de muito tempo e esforço para obter todas as informações necessárias para avaliar confortavelmente uma nova seguradora. Entretanto com relação ao custo de perda de relacionamento pessoal não foi significativa onde $90 \%$ do total não concordaram que sentiriam falta do relacionamento com as pessoas da atual seguradora. Em grande parte, isso se explica pela figura do corretor que ainda exerce um papel relevante na intermediação entre segurado e seguradora, distanciando um pouco esse relacionamento. Com relação às perdas monetárias e de benefícios apenas 30\% discordaram da afirmação que é caro pagar por todos os custos referentes à troca de seguro. Portanto, o esforço e a falta de tempo para avaliar alternativas aliado com a percepção de que existem muitas burocracias envolvidas na troca na seguradora aumenta a probabilidade do segurado manter o relacionamento com a seguradora atual. A maior parte das seguradoras exigem o preenchimento de um formulário para a cotação de um seguro de automóvel. Muitas vezes até o código do chassi é solicitado. Outra burocracia é o preenchimento do QAR (questionário de avaliação do risco) onde uma série de perguntas são feitas e que não são necessárias na renovação com a mesma seguradora.

A relação negativa entre atratividade das alternativas e lealdade, hipótese H5, foi confirmada, estando de acordo com o resultado obtido pelos autores Bansal et al. (2005), Hung (2006), Picón et al. (2014). Esse resultado pode indicar que a atratividade das alternativas atua como um fator que motiva e favorece a mudança para uma alternativa concorrente. Quanto maior a atratividade das alternativas disponíveis menor será a lealdade da marca atual. Conforme Bansal et al. (2005), o cliente percebendo que os concorrentes 
existentes no mercado podem oferecer um produto ou serviço com um melhor custo-benefício pode acabar terminando o relacionamento com a marca atual. No mercado de seguros nacional, é comum diferentes seguradoras de automóvel precificarem um mesmo seguro com valores diferentes. Se um cliente verifica a existência de outras seguradoras mais atrativas ele exibirá menor lealdade. Com maior atratividade das alternativas ele pode se sentir inclinado a trocar de seguro.

\subsection{3}

\section{Confiança}

A relação entre satisfação e confiança, hipótese H6, foi suportada e está de acordo com estudos anteriores Chaudhuri e Holbrook (2001) e Sirdeshmukh et al. (2002). Para os autores, a satisfação aumenta positivamente a confiança. A pesquisa aponta que a relação entre a satisfação e a confiança é a mais significativa com o coeficiente padronizado de 0,566. Assim, a seguradora deve atender a expectativa do cliente para aumentar sua satisfação gerando maior confiança. Sirdeshmukh et al. (2002) sugere que a confiança é baseada na percepção de que a empresa tem capacidade de desempenhar sua função declarada e é responsável pelo interesse e bem-estar do cliente. Dentro do seguro, clientes muitos satisfeitos podem ter confiança na dimensão da competência, se baseando na expectativa de um desempenho satisfatório da seguradora. Como uma apólice de seguro representa uma proteção financeira contra riscos futuros é imprescindível a confiança na formação de um relacionamento com uma seguradora. Ela deverá ser capaz de honrar seus compromissos em algum evento desfavorável. A satisfação no seguro também pode ocorrer na prestação de serviços emergenciais como reboque ou mecânico que pode aumentar a percepção de benevolência já que esse tipo de assistência pode trazer um bem-estar físico e psicológico. Por fim, como o contrato de seguro é pautado pela boa-fé, quando uma seguradora efetua um pagamento uma indenização, o segurado pode ter maior confiança em sua dimensão da integridade.

A relação entre confiança e lealdade, hipótese $\mathrm{H} 7$, foi confirmada e está de acordo estudos anteriores Chaudhuri e Holbrook (2001), Sirdeshmukh et al. (2002) e Aurier e N'Goala (2010). O resultado foi significativo com um coeficiente padronizado de 0,490. Uma explicação para esta relação direta e positiva da confiança na lealdade é a de que o segurado se baseia na crença de um pagamento de uma indenização em caso de um eventual prejuízo. Desta forma, 
é natural que a confiança na seguradora seja um antecedente da lealdade do cliente de seguros de automóvel. Este resultado corrobora com o estudo de Sirdeshmukh, Singh e Sabol (2002), que sugerem que a dimensão da competência é fundamental para o desenvolvimento da confiança e se baseia na expectativa de um desempenho satisfatório e qualificado por parte da seguradora. $\mathrm{Na}$ pesquisa identificamos que o fator mais importante na contratação de um seguro de automóvel para os respondentes é a credibilidade e a reputação da seguradora. Sendo que para $61 \%$ dos respondentes afirmam acreditar que sua seguradora atual é integra. Ou seja, a pesquisa demostra a dimensão integridade da confiança como importante na construção de um relacionamento de longo prazo. O resultado está alinhado com outros estudos sobre a confiança (DWYER et al., 1987, PALMATIER et al., 2006) onde autores afirmam que a confiança existe quando uma das partes acredita na integridade do parceiro de troca.

\subsection{4 \\ Resultados Gerais}

Os resultados da modelagem realizada (Figura 4.3) indicam que a satisfação é um antecedente significativo na lealdade de clientes (coeficiente padronizado 0,247, p-valor < 0,001) e que apresentou uma relação negativa com a variável atratividade das alternativas (coeficiente padronizado -0,314, p-valor < $0,001)$ todavia não demonstrando uma relação significativa com o custo de troca (coeficiente padronizado $-0,054$, p-valor $=0,45$ ). Por fim, a satisfação também possui uma relação significativa com a confiança (coeficiente padronizado 0,566 , p-valor $<0,001)$.

O custo de troca se mostrou um construto importante no processo de construção da lealdade. Sua relação com a lealdade foi significativa (coeficiente padronizado 0,252 , p-valor $<0,001)$. Outro resultado que pode ser identificado é o efeito negativo da atratividade das alternativas sobre a lealdade (coeficiente padronizado $-0,167, p$-valor $=0,007)$. A confiança apresentou um resultado que demonstra que é um antecedente significativo na lealdade (coeficiente padronizado 0,490, p-valor <0,001). 


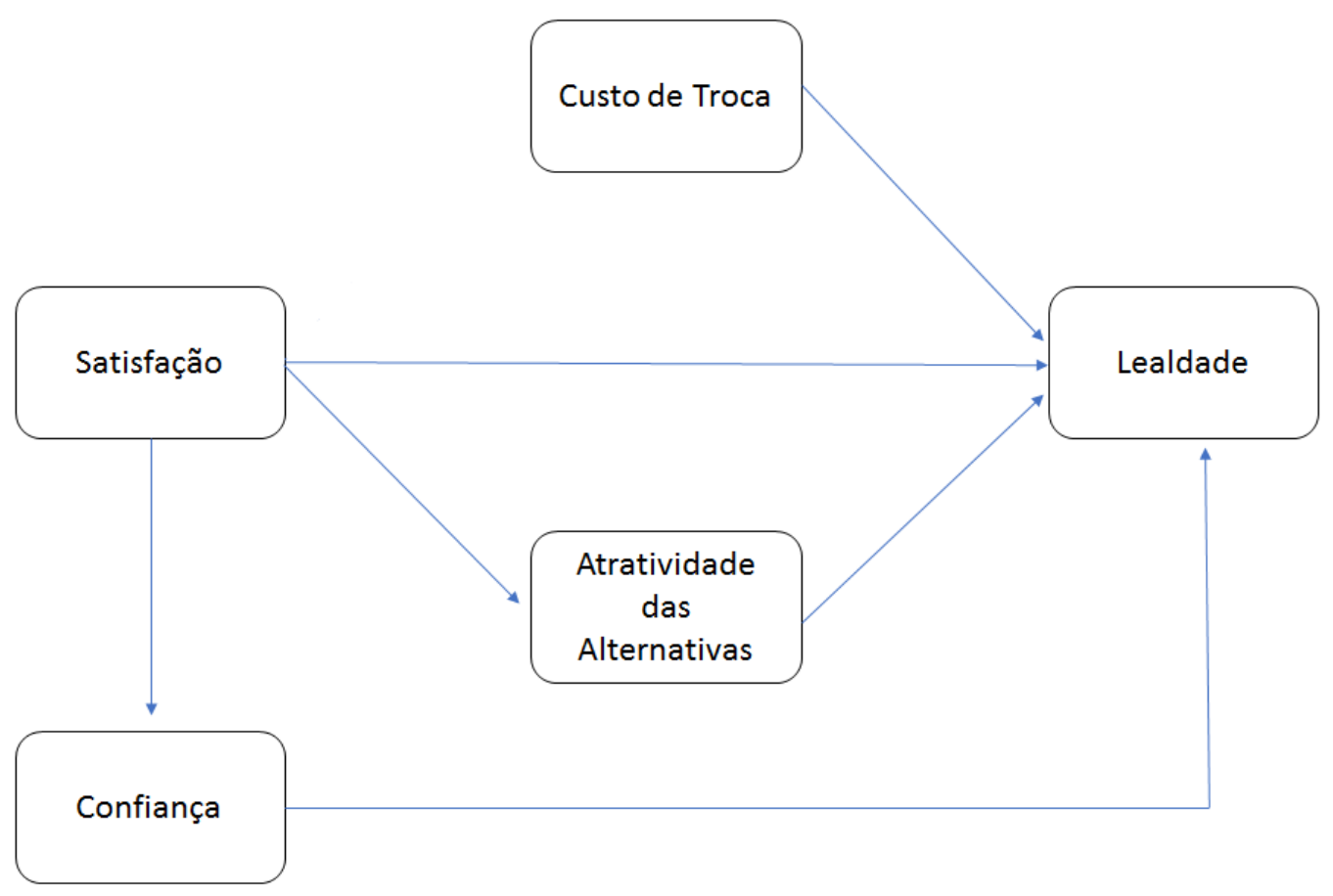

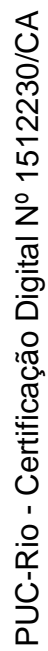

Figura 4.3: Resultado Final

Fonte: Própria 


\section{5 \\ Conclusões}

$\mathrm{Na}$ primeira parte deste capítulo se encontra um breve sumário da pesquisa realizada. Em seguida são abordados os impactos deste trabalho no estudo do tema da lealdade e são discutidas suas contribuições, tanto no âmbito teórico quanto no prático. Por último, são apresentadas as limitações do estudo e sugestão de pesquisas futuras são apontadas.

\section{1 \\ Sumário do estudo}

O presente estudo investigou a lealdade de indivíduos que utilizam carros com seguro de automóvel contratado nos últimos dois anos. Durante a pesquisa foi avaliada a maneira como satisfação, custo de troca, atratividade das alternativas e confiança se relacionam com a lealdade. Desta forma, buscou-se uma melhor compreensão sobre os fatores que influenciam a lealdade dos clientes de seguradoras de automóvel.

A revisão da literatura começou com uma visão geral sobre a lealdade especificamente no contexto das organizações empresariais, buscando apresentar a relevância de seu estudo para gestores e administradores de empresas. Através da revisão de Day (1969), Jacoby e Kyner (1973), Zeithaml et al. (1996), Oliver (1997,1999), Uncles, Dowling e Hammond (2003) e Valvi e Fragkos (2012) se destacou a evolução do conceito da lealdade e as principais particularidades nas visões desses autores. Essa discussão foi aplicada para o mercado de seguros, apresentando a lealdade como um ponto chave para o sucesso de companhias seguradoras de automóvel que atuam no país.

Alguns antecedentes, previamente identificados como relevantes na literatura, foram estudados a fundo juntamente com algumas características da lealdade. Com o propósito de aprofundar o conhecimento sobre a lealdade de clientes no mercado de seguros de automóvel, esta pesquisa desenvolveu um modelo baseado na pesquisa de Picón et al. (2014), que estudaram a relação de diversos antecedente da lealdade no mercado de seguros europeu, e de Aurier e N'Goala (2010), que pesquisaram sobre a importância da confiança na lealdade de clientes de bancos. 
Em seguida foi elaborado um instrumento de pesquisa composto por escalas pré-existentes, desenvolvidas e testadas anteriormente na literatura (PICÓN et al., 2004; AURIER e N'GOALA, 2010). Através deste instrumento de pesquisa foi realizada uma cross-sectional survey com uma amostra com 230 questionários válidos, respondidos voluntariamente por pessoas que utilizam carro com seguro de automóvel contratado pelo menos nos dois últimos anos da realização do estudo.

O modelo de mensuração, ajustado para os dados, indicou a confiabilidade e a validade dos construtos medidos por meio das escalas selecionadas, apresentando resultados adequados em acordo com estudos anteriores que fizeram uso das mesmas escalas.

As hipóteses de pesquisa foram verificadas com o uso de modelagem de equações estruturais. O modelo proposto mostrou que a satisfação, a confiança, a atratividade das alternativas e o custo de troca são antecedentes da lealdade de clientes no mercado de seguros. Outros resultados do modelo indicaram que a satisfação teve um efeito direto e positivo na confiança e um efeito direto e negativo na atratividade das alternativas. Ao mesmo tempo, os resultados não confirmaram efeito direto e positivo da satisfação no custo de troca.

\section{2 \\ Conclusões e implicações}

Os resultados verificados no presente estudo representam uma contribuição para o melhor entendimento da teoria do comportamento do consumidor, aprofundando o conhecimento sobre a lealdade dentro do mercado de seguros de automóvel. A intensa competitividade no setor de seguros estimula as seguradoras a buscarem uma fidelização de seus clientes. Esta lealdade deve ser consequência da vontade do cliente de manter o relacionamento com a empresa.

\section{2 .1}

\section{Implicações teóricas}

Primeiramente, o trabalho propõe um novo modelo a partir de pesquisas anteriores. O modelo proposto sugere outro olhar sobre os construtos estudados buscando uma perspectiva que permita a avaliação de novas relações.

O resultado do estudo confirma a importância da satisfação na lealdade, conforme apontado anteriormente por Dick e Basu (1994), Oliver (1997), Caruana (2002) e Picón et al. (2014) e sugere que a confiança é o construto com 
relação mais significativa na formação da lealdade, seguido pelo custo de troca e a atratividade das alternativas.

Outro resultado da pesquisa sugere que um cliente satisfeito percebe como menos atraentes as alternativas de concorrentes, isto é um cliente satisfeito é mais resistente às tentativas de persuasão da concorrência. Todavia, o resultado da pesquisa não pode confirmar que a satisfação aumenta o custo de troca percebido do segurado, dificultando a quebra do relacionamento do cliente com a seguradora atual. Por fim, a satisfação a pesquisa apontou que a satisfação possui uma relação direta e muito significativa na confiança.

\section{2 .2 \\ Implicações práticas}

Incialmente, o estudo evidencia a importância da satisfação do cliente e por isso a seguradora deve investir na qualidade do atendimento, no treinamento de seus colaboradores, na personalização de serviços e diversificação de coberturas que proporcione uma apólice que atenda todas as necessidades dos segurados. Buscando maior nível de satisfação, as seguradoras evitarão que seus clientes procurem e se interessem pela concorrência, diminuindo assim a atratividade das alternativas. Outra estratégia da seguradora pode ser 0 desenvolvimento de tecnologias que aproximem o segurado, estreitando seu relacionamento que pode estar muito concentrado no papel do corretor. Com relação ao custo de troca, muitos respondentes afirmaram que não concordam que exista muita perda financeira na troca de uma seguradora. Por lei, o cliente fica livre para trocar de seguradora a cada ano pela vigência da apólice ser obrigatoriamente anual. A seguradora pode se esforçar por criar mecanismos que aumentem a percepção de perda, criando barreiras para o rompimento do relacionamento. Por fim, o fator considerado pelos respondentes como o mais importante na contratação de um seguro é a credibilidade da seguradora, por isso é importante que as seguradoras se esforcem para o fortalecimento da marca passando uma imagem de integridade para seu cliente.

\section{3}

\section{Limitações do estudo}

Uma limitação da pesquisa é referente à coleta dos dados. Apesar do instrumento de pesquisa ter sido aplicado somente para respondentes que tivessem conhecimento sobre seguros de automóvel, com o respondente sendo levado a pensar no seu relacionamento com a sua seguradora de automóvel 
durante o preenchimento, a falta de experiência ou conhecimento sobre o assunto pode ter influenciado a qualidade de algumas respostas. Para minimizar essa limitação, o ideal seria que o questionário fosse aplicado após a renovação anual do seguro ou após o pagamento de alguma indenização, mas esse processo exigiria um acordo com as seguradoras que não foi viável para este estudo.

Em relação à validade externa dos resultados, uma vez que os dados refletem a visão principalmente de segurados do estado do Rio de Janeiro com razoável nível econômico, é possível que as relações verificadas na pesquisa não sejam generalizáveis para todo e qualquer tipo de cliente de seguro.

Outra limitação da pesquisa é a avaliação de somente alguns construtos relacionados à lealdade em decorrência da necessidade de manter o questionário dentro de um limite aceitável de tempo para resposta. Apesar de terem sido testados construtos apontados como relevantes na literatura, alguns aspectos, como a indicação de terceiros e a influência de preço não foram abordados na pesquisa. Assim, apesar da possibilidade de outros testes, acredita-se que os achados dessa pesquisa sejam um importante passo para uma melhor compreensão da lealdade no mercado de seguros de automóvel.

\section{4 \\ Sugestões para pesquisas futuras}

Dadas as limitações apresentadas, a realização de estudos similares com uma amostra mais numerosa e com perfil diferente do estudado neste trabalho, como, por exemplo, com clientes de outros estados e regiões do país, seria uma forma interessante de validar e ampliar o escopo dos resultados obtidos. Em função das características e particularidades de cada tipo de seguro, aplicar o mesmo modelo com foco em outros ramos de seguros específico pode gerar outras conclusões e possivelmente implicações mais direcionadas e objetivas. Outras escalas e construtos também poderiam ser aplicados ao modelo, por exemplo os antecedentes do custo de troca que podem explicar de que forma esse construto impacta na lealdade, ampliando a compreensão da formação da lealdade no mercado de seguros de automóvel. Outra sugestão é pesquisar o papel do corretor de seguro na lealdade de um cliente dentro de uma seguradora. Avaliar os impactos desta intermediação na satisfação e na formação da lealdade. 


\section{6 \\ Referências bibliográficas}

AJZEN, I. Attitude theory and the attitude-behavior relation. New directions in attitude measurement, p. 41-57, 1993.

AAKER, D. A.; KUMAR, V., e DAY, G. S. Marketing Research. Wiley, 9 ed., 2006.

ALTMAN, I., e TAYLOR, D. A. Social Penetration: The Development of interpersonal Relationships. New York: Holt, Rinehart and Winston. 1973.

ANTÓN, C.; CAMARERO, C., e CARRERO, M. The mediating effect of satisfaction on consumers' switching intention. Psychology and Marketing, v.24, p.511-538. 2007.

AURIER, P., e N'GOALA, G. The differing and mediating roles of trust and relationship commitment in service relationship maintenance and development. Journal of the Academy of Marketing Science, v.38, n.3, p.303-325. 2010.

BABBIE, E. The practice of social research. Australia: Wadsworth Thomson Learning. 2001.

BAGOZZI, R. P., e PHILLIPS, L. Representing and Testing Organizational Theories: A Holistic Construal. Administrative Science Quarterly, v. 17, p. 459489, 1982.

BANSAL, H. S., TAYLOR, S. F., e ST. JAMES, Y. "Migrating" to new service providers: Toward a unifying framework of consumers' switching behaviors. Academy of Marketing Science Journal, v.33, p. 96-115. 2005.

BARROSO, C., e PICÓN, A. Multi-dimensional analysis of perceived switching costs. Industrial Marketing Management, v.41, p.531-543. 2012.

BELL, D. E. Regret in Decision Making Under Uncertainty. Operations Research, v.30, p.961-981. 1982.

BENTLER, P. M. Comparative Fit Indices in Structural Models. Psychological Bulletin, v. 107, n. 2, p. 238-246, 1990.

BENTLER, $\mathrm{P}$, e BONNET, D. Significance test and goodness of fit in the analysis of covariance structures. Psychological Bulletin, v. 88, n. 3, p. 588-606, 1980. 
BURNHAM, T. A.; FRELS, J. K., e MAHAJAN, V. Consumer switching costs: a typology antecedents, and consequences. Journal of the Academy of Marketing Science, v. 31, n. 2, p. 109-126, 2003.

BUTCHER, K.; SPARKS, B., e O'CALLAGHAN, F. Evaluative and relational influences on service loyalty. International Journal of Service Industry Management. v.12, n. 4, p. 310-327, 2001.

BYRNE, B. M. Structural Equation Modeling with AMOS: Basic Concepts, Applications and Programming. 2a ed. Routledge, NY, 2010.

CARUANA, A. Service loyalty: The effects of service quality and the mediating role of customer satisfaction. European Journal of Marketing, v. 36, n. 7/8, p. 811-828. 2002.

CHEN, M. F., e WANG, L. H. The moderating role of switching barriers on customer loyalty in the life insurance industry. The Service Industries Journal, v.29, p.1105-1123. 2009.

CHAUDHURI, A., e HOLBROOK, M. B. The chain of effects from brand trust and brand affect to brand performance: the role of brand loyalty. Journal of Marketing, v.65, n.2, p. 81-93. 2001.

CHURCHILL, G. A. A Paradigm for Developing Better Measures of Marketing Constructs. Journal of Marketing, v. 16, p. 64-73, 1979.

CNSEG. Confederação Nacional das Empresas de Seguros Gerais, Previdência Privada e Vida, Saúde Suplementar e Capitalização. Estatística de Mercado. Rio de Janeiro, 2016 Disponível em: < http://www.cnseg.org.br/cnseg/estatisticas/> Acesso em: 11 de março 2017.

COOPER, D. R., e SCHINDLER, P. S. Métodos de Pesquisa em Administração. 7 ed. Porto Alegre: Bookman, p.640. 2003.

CRONIN, J., e Taylor, S. "Measuring service quality: a reexamination and extension", Journal of Marketing, v.56, n. 3, p. 55-68. 1992,

CUNNINGHAM, R.M. Brand loyalty - what, where, how much. Harvard Business Review, v. 39, November-December, p. 116-38, 1956.

DAY, G.S. "A two-dimensional concept of brand loyalty". Journal of Advertising Research, v. 9, p. 29-35, 1969.

DICK, A. S., BASU, K. Customer loyalty: toward an integrated conceptual framework. Journal of the Academy of Marketing Science. v. 22, spring, p. 99113, 1994.

DUBÉ, L.; MAUTE, M. F. Defensive strategies for managing satisfaction and loyalty in the service industry. Psychology \& Marketing, v. 15, n. 8, p. 775-791, 1998.

DWYER, D.; SCHURR, P., E OH, S. Developing buyer-seller relationships. Journal of Marketing, v.51, n.2, p.1-27. 1987. 
DWYER, F. R., e LAGACE, R. On the Nature and Role of Buyer-Seller Trust. AMA Summer Educators Conference Proceedings, eds. Chicago: American Marketing Association, p.40-45. 1986.

FERREIRA, J. B. Aceitação e prontidão do consumidor para produtos de alta tecnologia: Elaboração e teste empírico do modelo CART para adoção de produtos de alta tecnologia. [s.I.] Tese (Doutorado em Administração) Universidade Federal do Rio de Janeiro - UFRJ, Instituto COPPEAD de Administração, 2010.

FORNELL, C. A national customer satisfaction barometer: the Swedish experience. Journal of Marketing, v. 56, n. 1, p. 6-21, 1992.

FORNELL, C., e LARCKER, D. F. Evaluating Structural Equation Models with Unobservable Variables and Measurement Error. Journal of Marketing Research, v. 18, fevereiro, p.39-50, 1981.

FUNENSEG. Fundação Escola Nacional de Seguros. Teoria geral do seguro. Rio de Janeiro: Funenseg, 2010.

GARBARINO, E., e JOHNSON, M. The different roles of satisfaction, trust and commitment for relational and transactional consumers. Journal of Marketing, Chicago, Iss. 2, v. 63, p. 70-87, 1999.

GARVER, M. S., e MENTZER, J. T. Logistics Research Methods: Employing Structural Equation Modeling to Test for Construct Validity. Journal of Business Logistics, v. 20, p. 33-57, 1999.

GREMLER, D. D, e BROWN, S. W. The loyalty ripple effect: appreciating the full value of customers. International Journal of Service Industry Management. v. 10, n. 3, p. 271- 291, 1999.

GREMLER, D.; BROWN, S.; BITNER, M. J.; e PARASURAMAN, A. Customer loyalty and satisfaction: What resonates in service context? Working Paper. Bowling Green State University. 2001.

HAGHIGHI,M.; DOROSTI,A.; RAHNAMA, A., e HOSEINPOUR, A. Evaluation of factors affecting customer loyalty in restaurant industry. African Journal of Business Management, v.6, n.14, p.5039-5046. 2012.

HAIR, J. F.; BLACK, W. C.; BABIN, B. J., e ANDERSON, R. E. Multivariate Data Analysis,. 7a ed., Upper Saddle River: Prentice-Hall, 2009.

HART, S., SMITH, A., SPARKS, L. e TZOKAS, N. Are loyalty schemes a manifestation of relationship marketing, Journal of Marketing Management, v.15, n.6, p.541-562. 1999.

HAU, L. N, e THUY, P. N. Impact of service personal values on service value and customer loyalty: a cross-service industry study. Service Business. V.6, n.2, p.137-155. 2012. 
HOOPER, D.; COUGHLAN, J., e MULLEN, M. R. Structural Equation Modelling: Guidelines for Determining Model Fit. The Electronic Journal of Business Research Methods, v. 6, n. 1, p. 53 - 60, 2008.

HU, L. T.; BENTLER, P. M. Cutoff Criteria for Fit Indexes in Covariance Structure Analysis: Conventional Criteria Versus New Alternatives. Structural Equation Modeling, v. 6, n. 1, p. 1-55, 1999.

HUNG, J., SILVERTHORNE. Organization communication, job stress, organizational commitment, and job performance of accounting professionals in Taiwan and America, Leadership \& Organization Development Journal, v.27, n.4, p.242-249. 2006.

HUNT, H. KEITH. 1977. Overview and Future Research Direction. in Conceptualization and Measurement of Consumer Satisfaction and Dissatisfaction. H. Keith Hunt, ed. Cambridge, MA: Marketing Science Institute.

IBGE. INSTITUTO BRASILEIRO DE GEOGRAFIA E ESTATÍSTICA. Infográficos: frota municipal de veículos. Rio de Janeiro, 2016 Disponível em: <http://www.ibge.com.br/>. Acesso em: 20 de fevereiro. 2017.

JACOBY, J., e CHESTNUT, R.W. Brand Loyalty, Measurement and Management. New York: John Wiley, p.120. 1978.

JACOBY, J. A model of multi-brand loyalty. Journal of Advertising Research. v. 11, p. 25-31, 1971.

JACOBY, J., KYNER, D. B. Brand loyalty vs. repeat purchasing behavior. Journal of Marketing Research, v.10, p. 1-9, 1973.

KAHN, B.E.; KALWANI, M.U.; MORRISON, D.G. Measuring Variety Seeking and Reinforcement Behaviors Using Panel Data. Journal of Marketing Research, $v$. 23, p. 89-100, 1986.

KANTSPERGER, R, e KUNZ, W. H. Consumer trust in service companies: a multiple mediating analysis. Managing Service Quality, v.20, n.1, p.4-25. 2010.

KPMG AUDITORES INDEPENDENTES. Situação Atual e Perspectivas do Mercado de Seguros no Brasil. Rio de Janeiro, 2014 Disponível em: < http://www.kpmg.com/BR/PT/Estudos_Analises/artigosepublicacoes/Documents/ pesquisa-seguros-2014.pdf/>. Acesso em: 27 de janeiro. 2017.

KULVIWAT, S.; BRUNER II, G. C.; KUMAR, A.; NASCO, S. A.; CLARK, T. Toward a Unified Theory of Consumer Acceptance Technology. Psychology \& Marketing, v. 24, n. 12, p. 1059-1084, 2007.

LARZELERE. R. E., e HUSTON, T. L. The Dyadic Trust Scale: Toward Understanding Interpersonal Trust in Close Relationships. Journal of Marriage and the Family, v.42, p.595-604. 1980.

LOOMES, G., e SUGDEN, R. Regret theory: An alternative theory of rational choice under uncertainty. Economic Journal, v.92, p.805-824. 1982. 
MAYER, R. C.; DAVIS, J. H., e SCHOORMAN, F. D. An integrative model of organizational trust. Academy of Management Review, v. 20, n. 3, p. 709-734, 1995.

MCCONNELL, J. D. The development of brand loyalty: An experimental study. Journal of Marketing Research, n. 5, p. 13-19, 1968.

MORGAN, R., e HUNT, S. The commitment-trust theory of relationship marketing, Journal of Marketing, Chicago, Iss. 3, v. 58, p. 20-38, 1994.

MURPHY P.; LACZNIAK G., e WOOD G. An ethical basis for relationship marketing: a virtue ethics perspective. European Journal of Marketing, v. 41, n. 1/2, p. 37-57, 2007.

NESSET, E., HELGESEN, $\varnothing$. Effects of switching costs on customer attitude loyalty to an airport in a multi-airport region. Transportation Research Part A v.67, p. 240-253. 2014.

NGOBO, P. V. Drivers of customers' cross-buying intentions. European Journal of Marketing, v.38, p.1129-1157. 2004.

OLIVER, R. L. Satisfaction, a behavioral perspective on consumers. London, Maidenhead, 1997.

OLIVER, R. L. Whence customer loyalty? Journal of Marketing, n. 63, v.33-44, 1999.

PALMATIER, R. W.; DANT, R. P.; GREWAL, D., e EVAN, K. R. Factors influencing the effectiveness of relationship marketing: a meta-analysis. Journal of Marketing, v. 70, n. 4, p.136-153, 2006.

PARASURAMAN, A., GREWAL, D.; KRISHNAN, R. Marketing Research. 2. ed., South-Western College Pub, 2006

PATTERSON, P. G., e SMITH, T. A cross-cultural study of switching barriers and propensity to stay with service providers. Journal of Retailing, v.79, p.107-120. 2003.

PICÓN, A.; RUIZ, C., e CASTRO, I. The relationship between satisfaction and loyalty: A mediator analysis. Journal of Business Research, v.67, n.5 , p. 746751. 2014.

POPPO, L., e SCHEPKER, D. J. Repairing Public Trust in Organizations. Corporate Reputation Review, v. 13, n. 2, p. 124-141, 2010.

PORTER, M. E. Competitive Strategy: Techniques for Analyzing Industries and Competitors, New York: The Free Press, 1980.

REICHHELD, F. F., SASSER, W. E., Zero defections: quality comes to services. Harvard Business Review 68, n.5, p.105-111. 1990 
REINARTZ, W.J., e KUMAR, V. On the profitability of long-life customers in a noncontractual setting: an empirical investigation and implications for marketing. Journal of Marketing, v. 64, n. 4, p. 17-35, 2000.

ROTTER, J. A new scale for the measurement of interpersonal trust. Journal of Personality, United Kingdom, Iss. 4, v. 35, p. 651-665, 1967.

SCHREIBER, J. B; NORA, A., STAGE, F. K; BARLOW, E. A., e KING, J. Reporting Structural Equation Modeling and Confirmatory Factor Analysis Results: A Review. Journal of Educational Research, n.6, v. 99, p. 323-338. 2006.

SHARMA, N. The role of pure and quasi-moderators in services: An empirical investigation of ongoing customer-service-provider relationships. Journal of Retailing and Consumer Services, v.10, p. 253-262. 2003.

SHARP, B., e SHARP, A. Loyalty programs and their impact on repeat-purchase loyalty patterns, International Journal of Research in Marketing, v. 14, n. 5, p. 473-86, 1997.

SHETH, J., e PARK, W. A. Theory of Multidimensional Brand Loyalty. Advances in Consumer Research, v.1, p. 449-459, 1974.

SIRDESHMUKH, D.; SINGH, J., e SABOL, B. Consumer Trust, Value, and Loyalty in Relational Exchanges. Journal of Marketing, v. 66, n. 1, p. 15-37, 2002.

SPERBER, A. D. Translation and validation of study instrument for cross-cultural research. Gastroenterology, v. 126, n. 1, p. 124-128, 2004.

SULTAN, P.; WONG, H. Y. Antecedents and consequences of service quality in a higher education context: a qualitative research approach. Quality Assurance in Education, v. 21, n. 1, p. 70-95, 2013.

SUSEP. Superintendência de Seguros Privados. Notícias. 2016. Disponível em: <http://www.susep.gov.br/setores-susep/noticias/setor-de-seguros>. Acesso em: 12 fevereiro 2017.

TSAI, H.; HUANG, H.; JAW, Y., e CHEN, W. Why on-line customers remain with a particular E-retailer: An integrative model and empirical evidence. Psychology and Marketing, v.23, p. 447-464, 2006.

TUCKER, W. T. The Development of Brand Loyalty. Journal of Marketing Research, v. 1, p. 32-35, 1964.

UNCLES, M.D.; DOWLING, G.R, e HAMMOND, K. Customer loyalty and customer loyalty programs. Journal of Consumer Marketing, v. 20, n.4, p. 294316, 2003. 
VALVI, A.C., FRAGKOS, K. C. Critical review of the e-loyalty literature: a purchase-centred framework. Electronic Commerce Research v.12, p.331-378, 2012.

WANG, Y.S.; TANG, T.I.; TANG, e J.T.E. An instrument for measuring customer satisfaction toward web sites that market digital products and services. Journal of Electronic Commerce Research, v.2, n.3:89-102, 2001.

YIM, C.K., e KANNAN, P.K. Consumer Behavioral Loyalty: A Segmentation Model and Analysis. Journal of Business Research, v. 44, n. 2, pp. 75-92, 1999.

ZEITHAML, V. A.; BERRY, L. L., e PARASURAMAN, A. The behavioral consequences of service quality. Journal of Marketing, v.60, p. 31-46. 1996. 


\section{Apêndice A - Questionário utilizado na pesquisa}

Caro(a) entrevistado(a),Este questionário servirá de apoio para elaboração de uma dissertação de mestrado.Seu caráter é puramente acadêmico, sem fins comerciais. Esta pesquisa não conta com patrocínio de nenhuma seguradora, nem de qualquer outra empresa.

Algumas breves indicações que podem ajudar o preenchimento:

1. Por favor, leia com atenção as frases e responda a todas segundo a sua opinião.

2. A seguir você deve considerar como "minha seguradora de automóvel" a sua seguradora de automóvel atual ou que já tenha feito seguro de automóvel pelo menos nos últimos 2 anos.

3. NÃO existe resposta certa ou errada. O que vale é sua opinião!

Desde já muito obrigado. Sua colaboração é muito valiosa.

O carro que você utiliza já teve algum seguro de automóvel contratado nos últimos 2 anos?

O $\operatorname{Sim}$

O Não

Você participa da negociação e contratação do seguro de automóvel juntamente com o corretor?

O $\mathrm{Sim}$

O Não

Por quantos anos possui seguro de automóvel contratado?

O 1 a 2 anos

O 3 a 5 anos

O 5 a 10 anos

O Mais de 10 anos 
Qual é a sua seguradora de automóvel?

O Allianz

O Bradesco

O Itaú

O SulAmérica

O Azul

O Generali

O Liberty

O Tokio Marine

O BB Mapfre

O HDI

O Porto Seguro

O Outros

Já teve alguma indenização paga pela seguradora decorrente de algum sinistro (prejuízo)?

O Sim

O Não

Alguma indenização recusada?

O Sim

O Não

Já utilizou algum serviço da assistência 24 horas como reboque, mecânico ou chaveiro?

O Sim

O Não

Você imagina a possibilidade de deixar seu carro sem a contratação de seguro?

O Sim

O Não

Na sua opinião, o seguro de automóvel custa muito caro?

O Sim

O Não

Determine o fator mais importante na contratação de um seguro de automóvel?

O Credibilidade e reputação da seguradora

O Indicação do corretor ou de terceiros

O Preço e forma de pagamento

O Qualidade no atendimento e rapidez

O Tipos de coberturas e serviços disponíveis

Por favor, responda um pouco sobre você: 
Idade:

O 18 a 30 anos

O 30 a 50 anos

O Mais de 50 anos

Sexo:

O Masculino

O Feminino

Você estima que sua renda familiar média esteja em que faixa de valores:

O Abaixo de 1.000 reais

O 1.000 a 5.000 reais

O 5.000 a 10.000 reais

O Acima de 10.000 reais

Marque o seu grau de concordância ou discordância em cada uma das afirmativas abaixo, conforme sua opinião sobre sua seguradora de automóvel:

A minha seguradora de automóvel atende as minhas necessidades.

O Discordo totalmente

O Discordo parcialmente

Nem concordo, nem discordo

O Concordo parcialmente

O Concordo totalmente

A minha seguradora de automóvel é boa, ou é até melhor do que as concorrentes.

O Discordo totalmente

O Discordo parcialmente

O Nem concordo, nem discordo

O Concordo parcialmente

O Concordo totalmente

Minhas solicitações ou problemas são sempre resolvidos de maneira adequada por minha seguradora de automóvel.

O Discordo totalmente

O Discordo parcialmente

O Nem concordo, nem discordo

O Concordo parcialmente

O Concordo totalmente

A minha seguradora de automóvel é muito competente.

O Discordo totalmente

O Discordo parcialmente

O Nem concordo, nem discordo

O Concordo parcialmente

O Concordo totalmente 
A minha seguradora de automóvel me presta o serviço que espero dela.

O Discordo totalmente

O Discordo parcialmente

O Nem concordo, nem discordo

O Concordo parcialmente

O Concordo totalmente

A minha seguradora de automóvel me presta um excelente serviço.

O Discordo totalmente

Discordo parcialmente

O Nem concordo, nem discordo

O Concordo parcialmente

O Concordo totalmente

Em geral, a minha experiência com a minha seguradora de automóvel é positiva.

O Discordo totalmente

O Discordo parcialmente

O Nem concordo, nem discordo

O Concordo parcialmente

O Concordo totalmente

Eu não disponho de tempo para buscar informações completas para avaliar outras seguradoras de automóvel.

O Discordo totalmente

O Discordo parcialmente

O Nem concordo, nem discordo

O Concordo parcialmente

O Concordo totalmente

Eu considero que é preciso muito tempo e esforço para obter todas as informações necessárias para me sentir confortável avaliando novas seguradoras de automóvel.

O Discordo totalmente

D Discordo parcialmente

O Nem concordo, nem discordo

O Concordo parcialmente

O Concordo totalmente

Mudar para uma outra seguradora de automóvel implicaria em algum custo financeiro inicial (tarifas, taxas de adesão, depósitos, etc.)

O Discordo totalmente

O Discordo parcialmente

O Nem concordo, nem discordo

O Concordo parcialmente

O Concordo totalmente 
Na minha opinião, é caro pagar por todos os custos referentes à troca de seguradoras.

O Discordo totalmente

O Discordo parcialmente

O Nem concordo, nem discordo

O Concordo parcialmente

O Concordo totalmente

Mudar para uma nova seguradora de automóvel significaria perder ou substituir bônus, descontos, créditos, duração de serviços e assim por diante, que eu acumulei com minha seguradora de automóvel atual.

O Discordo totalmente

O Discordo parcialmente

O Nem concordo, nem discordo

O Concordo parcialmente

O Concordo totalmente

Eu perderia muitos descontos, bônus, créditos, pontos acumulados e serviços que eu já paguei, se eu mudar para uma nova seguradora de automóvel.

O Discordo totalmente

O Discordo parcialmente

O Nem concordo, nem discordo

O Concordo parcialmente

O Concordo totalmente

Se eu trocar de seguradora de automóvel, eu perderia os benefícios de ser um cliente de longa data.

O Discordo totalmente

O Discordo parcialmente

O Nem concordo, nem discordo

O Concordo parcialmente

O Concordo totalmente

Trocar de seguradora de automóvel envolve um processo de vendas desagradável.

O Discordo totalmente

O Discordo parcialmente

O Nem concordo, nem discordo

O Concordo parcialmente

O Concordo totalmente

Existem muitas formalidades (burocracia) envolvidas na troca de seguradora de automóvel.

O Discordo totalmente

O Discordo parcialmente

O Nem concordo, nem discordo

O Concordo parcialmente

O Concordo totalmente 
Eu sentiria falta do relacionamento com as pessoas da minha seguradora de automóvel atual se trocasse para outra.

O Discordo totalmente

O Discordo parcialmente

O Nem concordo, nem discordo

O Concordo parcialmente

O Concordo totalmente

Eu me sinto mais confortável interagindo com as pessoas que trabalham na minha seguradora de automóvel atual do que me sentiria se eu trocasse para uma outra.

O Discordo totalmente

O Discordo parcialmente

O Nem concordo, nem discordo

O Concordo parcialmente

O Concordo totalmente

Eu gosto de conversar / interagir com as pessoas das empresas que me prestam serviços.

O Discordo totalmente

O Discordo parcialmente

O Nem concordo, nem discordo

O Concordo parcialmente

O Concordo totalmente

Trocar para uma nova seguradora de automóvel provavelmente envolverá custos não tão claros.

O Discordo totalmente

Discordo parcialmente

O Nem concordo, nem discordo

O Concordo parcialmente

O Concordo totalmente

Provavelmente farei um mau negócio financeiramente se eu mudar para uma nova seguradora de automóvel.

O Discordo totalmente

O Discordo parcialmente

O Nem concordo, nem discordo

O Concordo parcialmente

O Concordo totalmente

Trocar para uma nova seguradora de automóvel provavelmente resultará em algum aborrecimento inesperado.

O Discordo totalmente

O Discordo parcialmente

O Nem concordo, nem discordo

O Concordo parcialmente

O Concordo totalmente 
Eu acredito que uma outra seguradora de automóvel me beneficiaria mais do que minha seguradora atual.

O Discordo totalmente

O Discordo parcialmente

O Nem concordo, nem discordo

O Concordo parcialmente

O Concordo totalmente

Eu me sentiria mais satisfeito com os serviços de uma outra seguradora de automóvel do que eu sou com a minha atual.

O Discordo totalmente

O Discordo parcialmente

O Nem concordo, nem discordo

O Concordo parcialmente

O Concordo totalmente

Em geral, eu acredito que outra seguradora de automóvel custaria menos do que a minha atual.

O Discordo totalmente

O Discordo parcialmente

O Nem concordo, nem discordo

O Concordo parcialmente

O Concordo totalmente

Eu acho que uma nova seguradora de automóvel me ofereceria uma variedade mais completa de serviços.

O Discordo totalmente

O Discordo parcialmente

O Nem concordo, nem discordo

O Concordo parcialmente

O Concordo totalmente

Eu realmente gosto de ser cliente da minha seguradora de automóvel.

O Discordo totalmente

O Discordo parcialmente

O Nem concordo, nem discordo

O Concordo parcialmente

O Concordo totalmente

Para mim, a minha seguradora de automóvel é claramente a melhor para se fazer seguros.

O Discordo totalmente

O Discordo parcialmente

O Nem concordo, nem discordo

O Concordo parcialmente

O Concordo totalmente 
Eu acredito que a minha seguradora de automóvel é uma boa empresa.

O Discordo totalmente

O Discordo parcialmente

O Nem concordo, nem discordo

O Concordo parcialmente

O Concordo totalmente

Eu tento usar a minha seguradora toda vez que preciso de qualquer apólice de seguro.

O Discordo totalmente

Discordo parcialmente

O Nem concordo, nem discordo

O Concordo parcialmente

O Concordo totalmente

Eu considero a minha seguradora como a principal empresa do mercado segurador.

O Discordo totalmente

O Discordo parcialmente

O Nem concordo, nem discordo

O Concordo parcialmente

O Concordo totalmente

Eu considero a minha seguradora como a primeira escolha quando preciso contratar qualquer tipo de seguro.

O Discordo totalmente

O Discordo parcialmente

O Nem concordo, nem discordo

O Concordo parcialmente

O Concordo totalmente

Eu pretendo continuar a ser cliente da minha seguradora de automóvel nos próximos anos.

O Discordo totalmente

O Discordo parcialmente

O Nem concordo, nem discordo

O Concordo parcialmente

O Concordo totalmente

Enquanto a minha seguradora de automóvel existir, eu duvido que mudaria de seguradora.

O Discordo totalmente

O Discordo parcialmente

O Nem concordo, nem discordo

O Concordo parcialmente

O Concordo totalmente 
A minha seguradora de automóvel é altamente íntegra.

O Discordo totalmente

O Discordo parcialmente

O Nem concordo, nem discordo

O Concordo parcialmente

O Concordo totalmente

Eu posso contar que minha seguradora de automóvel faz o que é correto.

O Discordo totalmente

Discordo parcialmente

O Nem concordo, nem discordo

O Concordo parcialmente

O Concordo totalmente

A minha seguradora de automóvel se importa comigo.

O Discordo totalmente

O Discordo parcialmente

O Nem concordo, nem discordo

O Concordo parcialmente

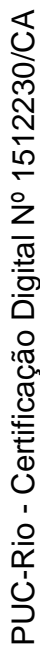

O Concordo totalmente

Se algum problema surgir, minha seguradora de automóvel é honesta com relação ao problema.

O Discordo totalmente

Discordo parcialmente

O Nem concordo, nem discordo

O Concordo parcialmente

O Concordo totalmente 